\title{
A COMPARATIVE EXPOSITION OF THE LAW OF HUSBAND AND WIFE IN TERMS OF ISLAMIC LAW, SOUTH AFRICAN LAW AND THE LAW OF ENGLAND AND WALES - PART TWO
}

\author{
Razaana Denson \\ BA LLB HDE LLM LLD \\ Advocate of the High Court \\ Lecturer, Private Law, Nelson Mandela \\ University
}

\section{SUMMARY}

The article discusses and compares the dissolution of a marriage as well as the legal consequences thereof in Islamic law, South African law and English law. This is done in order to demonstrate that despite similarities, there are vast differences between the three legal systems. This impacts on how Muslim personal law (MPL) can be recognised and regulated in South Africa and in England and Wales as constitutional democracies. South Africa, England and Wales share a commitment to human rights and have adopted various approaches in respect of accommodating the application of Islamic law. Internal pluralism also exists within the Muslim communities in South Africa, England and Wales as the majority of Muslims in these countries have to varying degrees developed diverse strategies to ensure compliance with Islamic law, as well as with South African and English law. Notwithstanding the accommodation of MPL in terms of South African and English law, the differences between these legal systems have resulted in decisions that, while providing relief to the lived realities of Muslims, are in fact contrary to the teachings and principles of Islam and therefore problematic for Muslims.

\section{$1 \quad$ INTRODUCTION}

The definition of the term "marriage" in all three legal systems clearly illustrates that a marriage should ideally only be terminated at the death of either spouse. ${ }^{1}$ Although Islamic, South African law and English law discourage divorce and encourage reconciliation between spouses, all three legal systems also recognise that, under certain circumstances, it may become impossible to continue with the marriage and that divorce is the only

All three legal systems advocate the view that when a marriage is concluded, the spouses enter into a life-long relationship. 
alternative. ${ }^{2}$ This is particularly so where cordial relations between the spouses become distinctly impossible. The parties should embark upon the termination of a marriage through divorce only as a measure of last resort. The reality in modern-day society is that divorce, like marriage, has become firmly entrenched in the familial and social lives of people. ${ }^{3}$

As a result, a comprehensive set of rules and principles regulating the dissolution of a marriage has been developed by the Islamic, South African and English legal systems so as to minimise the harmful effects that the dissolution of a marriage can have on the family, especially where there are children born of the marriage. The primary aim of rules and principles regulating the termination of a marriage is to promote social stability by reducing hostility between the spouses. It is also to ensure that equity prevails in respect of the economic consequences of the divorce. In addition to the economic consequences that require regulation, most of the personal consequences of a marriage end when the marriage is terminated. A discussion of the rules and principles regulating the dissolution of a marriage in the three legal systems follows.

\section{DISSOLUTION OF A MARRIAGE BY DEATH}

\section{Islamic law}

In terms of Islamic law, the dissolution of a marriage can be effected by the death of one of the spouses to the marriage. The matrimonial property regime of marriages concluded in terms of Islamic rites is one of complete separation of estates. ${ }^{4}$ According to authentic narrations from Islamic jurists, ${ }^{5}$ a person is only allowed to receive benefits and wealth that was earned through lawful means; if the parties are married in terms of a shared matrimonial property system, for example, one becomes entitled to receive benefits to which he or she is not Islamically entitled. ${ }^{6}$ Although there is also no sharing of assets at the termination of the marriage by death, both husband and wife can inherit from each other upon the death of the other spouse. ${ }^{7}$ Although Islam encourages parties to draw up a will, there is no real freedom of testation. ${ }^{8}$ This means that a testator cannot, for example,

2 Sabiq Fiqh Us-Sunnah (1989) 51; Esposito Islam the Straight Path (1991) 78 83. Barratt, Domingo, Amien, Denson, Mahler-Coetzee, Olivier, Osman, Schoeman and Singh Law of Persons and the Family (2017) 332; Herring Family Law (2011) 105-107.

3 Barratt et al Law of Persons and the Family 332; Gibson Dissolving Wedlock (1994).

4 Rautenbach and Bekker Introduction to Legal Pluralism (2014) 368; Ibn Katheer Tafseer alQuran al-Adheem vol 1 (2003) 93; Quran ch 4, verse 33. The matrimonial property system in terms of Islamic law is similar to the South African standard antenuptial contract where the accrual system is excluded.

5 Ibn Katheer Tafseer al-Quran al-Adheem vol 1 (2003) 93.

6 The Ulama in South Africa are unanimous that the only matrimonial property regime that is Shari'ah compliant is the standard antenuptial contract where there is no sharing of assets and liabilities during the subsistence of the marriage. This may prove to be problematic as the wife may be left destitute where all or most of the assets accrued during the subsistence of the marriage are registered in the husband's name.

7 Doi Women in Shari'ah (1989) 166.

$8 \quad$ Alkhuli The Light of Islam (1981) 97. 
disinherit one child or his wife, for that matter, as one of the principles of the Islamic law of inheritance is that the wife, the children born of the marriage and the parents of the husband or wife inherit in all cases, although not in equal shares. ${ }^{9}$ Islam limits the power of testamentary disposition to one-third of the testator's estate, as the remaining two-thirds must be distributed among the heirs. ${ }^{10}$ The rules of inheritance are, however, subject to the condition that, before the heirs inherit, all the deceased's debts, including funeral expenses, must first be settled and effect must be given to bequests and legacies. ${ }^{11}$

Maintenance (nafaqah) during the subsistence of the marriage is primarily the husband's duty, regardless of the private means of the wife. ${ }^{12}$ The wife is under no obligation to contribute financially towards the running of the household, and where she does, she may claim such amounts from her husband. ${ }^{13}$ When a marriage is terminated by the death of the husband, insofar as the maintenance of the surviving spouse is concerned, the surviving widow is allowed to be maintained from the estate of her deceased husband for a period of four months and ten days - namely, her period of iddah (mourning) ${ }^{14}$ after the death of her husband. Thereafter, the rules of inheritance come into effect. ${ }^{15}$

\section{South African law}

The dissolution of a civil marriage ${ }^{16}$ can occur through the death of one or both of the spouses. As soon as the marriage is terminated, the personal consequences of the marriage end - that is, the consortium omnis vitae and spousal maintenance duty come to an end. ${ }^{17}$ The manner in which the matrimonial property is divided upon the death of one or both of the spouses depends on the matrimonial property system that regulates their marriage.

\section{Marriages in community of property}

Where the parties were married in community of property prior to death, the marriage, as well as the community of property between the spouses, ends and each spouse is entitled to half of the joint spousal estate. ${ }^{18}$ The Administration of Estates Act ${ }^{19}$ regulates the winding up of the joint estate. In

$9 \quad$ Ibid.

10 Doi Women in Shariah 165. Examples of heirs are the wife, the children and the deceased's parents.

1 Alkhuli The Light of Islam 96.

12 Siddiqi The Family Laws of Islam 107.

3 Siddiqi The Family Laws of Islam 108.

14 Iddah is defined as a compulsory period of waiting or mourning, which a widow or divorcee is obliged to observe in terms of Islamic Law. In the case of a widow, the prescribed iddah is four months and ten days, and for the divorcee, the prescribed iddah is three months.

15 Ibn Katheer Tafseer al-Qur'anal-Adheem vol 1218.

16 This includes civil unions concluded in terms of the Civil Union Act 17 of 2006.

17 The surviving spouse of the deceased can claim maintenance from the deceased spouse's estate in terms of the Maintenance of Surviving Spouses Act 27 of 1990.

18 Voet 23.2.90; Grotius 2.11.13; Van Leeuwen 4.23.11.

1966 of 1965. 
terms of the Act, control of the joint estate is transferred to the executor for winding up before the surviving spouse receives his or her half-share of the joint estate. ${ }^{20}$ The executor has to pay all debts owed by the joint estate and exact payment for all debts that are owed to the joint estate. ${ }^{21}$ Only once the executor has discharged these duties is half the net balance of the joint estate delivered to the surviving spouse - by virtue of the matrimonial property system that regulated the marriage, not the laws of inheritance. ${ }^{22}$ The deceased spouse's net half of the joint estate is devolved among his or her heirs. As soon as the executor assumes control over the joint estate, the surviving spouse is only permitted to deal with the assets in the joint estate for specified purposes, ${ }^{23}$ unless he or she has the consent of the Master of the High Court to do otherwise. ${ }^{24}$

\section{Marriages out of community of property excluding accrual}

An antenuptial contract is not terminated by the death of one or both spouses, but rather by the fulfilment of all the conditions of the antenuptial contract. The executor deals only with the estate of the deceased spouse.

If the surviving spouse has any claim against the deceased estate, he or she must lodge a claim against the deceased estate with the executor. ${ }^{25}$ This can include a claim for household necessaries in terms of section 23 of the Matrimonial Property Act, ${ }^{26}$ where one spouse contributed more than his or her pro rata share to household necessaries. In cases where the parties were married out of community of property without accrual before 1 November 1984, an automatic right of recourse exists where one spouse contributed more than his or her pro rata share. Spouses who entered into a marriage after the coming into operation of the Matrimonial Property Act, no longer enjoy this automatic right of recourse. Spouses can, if they so wish, agree to a right of recourse in terms of their antenuptial contract. ${ }^{27}$

\section{Marriage out of community of property with accrual}

Where spouses are married in terms of the accrual system, the calculation of the accrual occurs when the marriage is terminated. A claim will be lodged against the deceased's estate where the accrual of the surviving spouse is less than that of the deceased. ${ }^{28}$ In contrast, where the deceased estate shows a smaller accrual, it is the duty of the executor to lodge a claim against the surviving spouse for the payment of the accrual.

20 Barratt et al Law of Persons and the Family 327.

21 Ibid.

22 Estate Sayle v Commissioner of Inland Revenue 1945 AD 388.

23 For example, funeral expenses and reasonable maintenance may be claimed from the joint estate.

24 Heaton and Kruger South African Family Law (2015) 116; Barratt et al Law of Persons and the Family 327.

25 Barnard v Van der Merwe 2012 (3) SA 304 (GNP).

2688 of 1984.

27 S 23(1) and (4) of the Matrimonial Property Act 88 of 1984.

28 Heaton and Kruger South African Family Law 116. 


\section{Claims of the surviving spouse}

In addition to the above consequences, where a marriage is dissolved through death, claims based on inheritance and maintenance also arise. Where the deceased has left a valid will, effect must be given to claims based on inheritance. Where the deceased died without a valid will, the rules of intestate succession, as set out in the Intestate Succession Act, ${ }^{29}$ will apply.

In terms of section 2(1) of the Maintenance of Surviving Spouses Act, ${ }^{30}$ a surviving spouse can also institute a claim against the deceased's estate for his or her reasonable maintenance needs until his or her death or remarriage, to the extent that she cannot provide for these needs from her own means and earnings. To determine what "reasonable maintenance needs" are, the court takes the following factors into consideration - namely, the amount available in the deceased estate for distribution to heirs and legatees, ${ }^{31}$ the surviving spouse's existing and expected means, earning capacity, financial needs and obligations, ${ }^{32}$ the duration of the marriage, ${ }^{33}$ the surviving spouse's standard of living during the marriage, ${ }^{34}$ the surviving spouse's age at the time of the deceased's death, ${ }^{35}$ and any other relevant factors. The amount claimed by the surviving spouse will, therefore, be reduced or denied if there are insufficient funds in the deceased's estate, ${ }^{36}$ or in situations where the surviving spouse is in a position to provide maintenance for him- or herself. The deceased's children also have a claim against the estate for their reasonable maintenance needs. ${ }^{37}$ The claim of the surviving spouse and the dependent children of the deceased has the same order of preference. In terms of section $2(3)(b)$, where the claims of the surviving spouse and the dependent children compete with one another, and the amount available in the deceased's estate is insufficient to meet the claims in full, these claims will be reduced proportionally.

Surviving spouses who are married in terms of the Recognition of Customary Marriages $\mathrm{Act}^{38}$ or the Civil Union Act, ${ }^{39}$ as well as surviving spouses married according to Muslim rites, ${ }^{40}$ qualify as "survivors" in terms of the Maintenance of Surviving Spouses Act. This does not apply to the surviving partner of a life partnership as the law does not impose a duty of support between unmarried persons. ${ }^{41}$

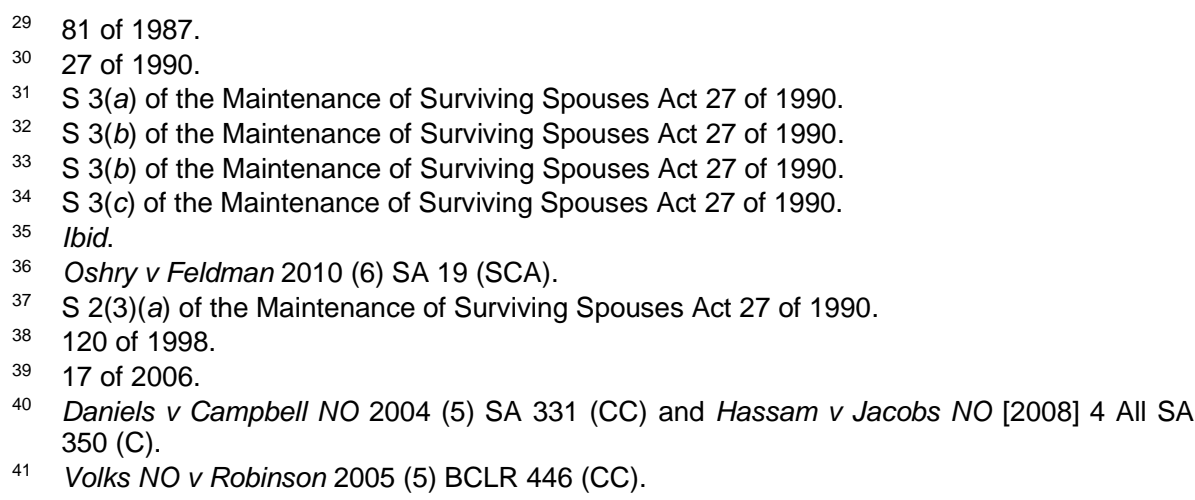


It must, however, be noted that the relief provided to a surviving Muslim spouse in terms of the Maintenance of Surviving Spouses Act is contrary to the principles of Islamic law as the wife is only entitled to maintenance from her deceased husband's estate during the iddah period. Thereafter, she becomes the responsibility of her guardian.

\section{The law of England and Wales}

A marriage is terminated by the death of one or both spouses..$^{42}$ At the death of a spouse, the surviving spouse automatically acquires a right to inherit assets from the estate where the deceased spouse died intestate. ${ }^{43}$ The surviving spouse furthermore acquires an automatic right to apply for financial provision from the deceased spouse's estate where the provision made for the surviving spouse is insufficient. ${ }^{44}$ The surviving spouse also has an action against third parties whose wrongful act caused the death of the deceased spouse. ${ }^{45}$

\section{Comparison}

In Islamic law, since the marriage involves complete separation of assets, the spouses cannot lay claim to each other's estates where the marriage is terminated by the death of one of the spouses. The spouses can, however, inherit from each other. In contrast, in terms of South African law, the division of the marital property depends exclusively on the matrimonial property system regulating the spouses' marriage. In English law, the surviving spouse automatically acquires a right to inherit from the estate of the deceased spouse unless the latter executes a valid will that excludes the surviving spouse. The surviving spouse is also entitled to lodge a claim for maintenance against the deceased spouse's estate.

The Islamic law of inheritance does not recognise freedom of testation; a husband cannot disinherit his wife while the marriage is still in existence. Both South African and English law allow the spouses freedom of testation. In terms of South African law, in particular, where the parties are married in community of property or subject to accrual, for example, one spouse can still prevent the other from inheriting his or her half-portion of the estate, or his or her portion of the accrual.

A further significant difference between Islamic law and the other two legal systems is that, at the termination of a marriage by death, both South African and English law permit the parties to enter into another marriage immediately. In contrast, Islamic law requires the woman to observe a period of mourning. This rule does not apply to the man where the parties were married in terms of Islamic rites, as he is allowed to enter into a marriage immediately upon the death of his wife.

Furthermore, in terms of Islamic law, after the death of her husband, the

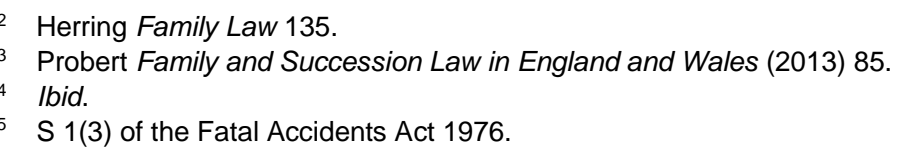


widow once again becomes the responsibility of her guardian, who is under an obligation to maintain her. The surviving spouse is only allowed to be maintained from the estate of her deceased husband for a period of four months and ten days after the demise of her husband. ${ }^{46}$ South African law makes provision for the widow of the deceased to claim for maintenance in terms of the Maintenance of the Surviving Spouses Act. ${ }^{47}$ As mentioned previously, a surviving spouse married according to Muslim rites ${ }^{48}$ qualifies as a "survivor" in terms of the Maintenance of Surviving Spouses Act, allowing the surviving spouse to lodge a claim for maintenance against the deceased spouse's estate. Although this claim is allowed in terms of South African law, it conflicts with the teachings and principles of Islamic law in terms of which the surviving wife becomes the responsibility of her guardian and is not allowed to lodge a claim against her deceased husband's estate. Similarly, English law also makes provision for the surviving spouse to lodge a claim for maintenance against the deceased spouse's estate.

\section{DISSOLUTION OF A MARRIAGE BY DIVORCE}

\section{Islamic law}

Where the marital relationship has broken down and the parties can no longer live together in peace and harmony, Islam recognises that termination of the marriage is inevitable. ${ }^{49}$ There is no value in keeping a marriage together when the union has been rendered meaningless and has no future owing to the breakdown of the marital relationship. ${ }^{50}$ The marriage will subsist only for as long as the spouses have love and respect for each other. ${ }^{51}$ Leaving matters unresolved where the marital relationship has broken down and where the spouses can no longer live together is regarded as un-Islamic and unethical on the part of spouses. ${ }^{52}$

Islam, therefore, recognises the necessity of divorce. While divorce is allowed in instances of absolute necessity, it is clear that Islam does not regard it as desirable. ${ }^{53}$ As Islam implores spouses to try their utmost to keep their marriage intact, the act of divorce should, therefore, be considered only as a last resort, after all attempts at reconciliation have failed.

46 Ibn Katheer Tafseer al-Qur'anal-Adheem 218.

47 S 7(2) of the Maintenance of Surviving Spouses Act 27 of 1990.

48 Daniels v Campbell NO supra and Hassam v Jacobs NO supra.

49 Ur-Rahman Muhammad: Encyclopedia of Seerah vol 2 (1989) 58; Moosa Unveiling the Mind (2004) 117.

50 Keene Believers in One God (1983) 168.

51 Ayoup Fiqh of Muslim Family (undated) 182.

52 Quran ch 4, verse 129.

53 Ayoup Fiqh of Muslim Family 185; Quran ch 4, verse 19. 


\section{Definition of divorce}

The literal meaning of the word talaq is to "set free". ${ }^{4}$ In terms of Islamic law, talaq is defined as "the dissolution of a valid marriage contract forthwith or at a later date by the husband, his agent, or his wife duly authorised by him to do so, using the word talaq, a derivative or a synonym thereof". ${ }^{55}$ From the definition, certain deductions can be made. First, the right of talaq as a method of terminating the marriage is generally exclusively reserved for the husband; 56 furthermore, the right of talaq is entirely at the discretion of the husband. ${ }^{57}$ Where the husband is guilty of misconduct, ${ }^{58}$ and the wife wishes to terminate the marriage as a result thereof, she is required to apply to the relevant Muslim authority 59 for the annulment (faskh) of the marriage. 60 Secondly, the husband may appoint or delegate someone to pronounce the divorce on his behalf. ${ }^{61}$ Thirdly, Shari'ah does not prescribe any formalities in respect of the manner in which the divorce must be pronounced. ${ }^{62}$ For example, no witnesses are required to be present at the time that the talaq is pronounced, nor is the presence or the consent of the wife required for the talaq. 63

\section{Pre-divorce procedure}

Before a divorce is issued, all attempts must be undertaken to reconcile the parties. ${ }^{64}$

In the interests of fairness and justice, the Quran advocates the appointment of an arbiter from the family of each spouse. ${ }^{65}$ The role of the two appointed arbiters is to assist the spouses in the reconciliation process by probing into the real cause of the disharmony between the spouses, and to assist the spouses to find a solution to the dispute. ${ }^{66}$ According to the Shafi'i school of Islamic jurisprudence, the arbiters are not authorised to pass any final decree, but are permitted to make recommendations for reconciliation between the spouses. ${ }^{67}$ These recommendations may either be accepted or rejected by the spouses. ${ }^{68}$ However, if the spouses authorise the arbiters to effect a divorce, or to take any other measure, they will be

54 Doi Shari'ah: The Islamic Law (1984) 168.

55 Nasir The Status of Women Under Islamic Law (2009) 120.

56 Ba'-kathah Tuh-fatul Ikhwaan (1987) 164; Doi Women in the Shari'ah 84.

57 Rautenbach and Bekker Introduction to Legal Pluralism 374.

58 For example, failing to maintain the wife or cruelty on the part of the husband towards the wife. See Moodley "The Islamic Laws of Divorce, Polygamy and Succession" 2001 42(2) Codicillus 9; Rautenbach and Bekker Introduction to Legal Pluralism 379.

59 The Ulama or one of the Judicial Councils will suffice as a relevant Muslim authority.

60 Ba'-kathah Tuh-fatul Ikhwaan 165.

61 Sabiq Fiqh Us-Sunnah 128.

2 Ahmad The Muslim Law of Divorce (1984) 28-30; Moosa Unveiling the Mind 118.

63 Sabiq Figh Us-Sunnah 128.

64 Quran ch 4, verse 35

65 Alkhuli The Light of Islam 84.

66 Ibid.

67 Siddiqi The Family Laws of Islam (1984) 217.

68 Ibid. 
deemed to be bound by their decision. ${ }^{69}$ Only if all attempts at reconciliation have failed, may a divorce be sought. ${ }^{70}$ Reconciliation between the two spouses is encouraged as far as possible. ${ }^{71}$

\section{Grounds for divorce}

Divorce is permitted when married life is a source of misery and unhappiness for the spouses to the marriage. ${ }^{72}$ Besides the breakdown of the marital relationship, a divorce may also be sought if the husband is impotent or sterile, or the wife is chronically ill. ${ }^{73}$ The spouses are allowed to part ways where, as far as temperament is concerned, they are incompatible to such an extent that they cannot live together in marital agreement. ${ }^{74}$ The wife is also allowed to seek a divorce if the husband is serving a sentence of life imprisonment, or is absent and his whereabouts are unknown, or where the husband is unable to bear the financial responsibility of maintaining his wife. ${ }^{75} \mathrm{~A}$ further ground for divorce is the misconduct of either the husband or the wife ${ }^{76}$ - for example, if either the wife or the husband commits adultery. In this instance, an action for divorce can be instituted.

\section{Forms of divorce}

There are various verses of the Quran indicating that a divorce may be effected orally or in writing, in the presence of two competent witnesses. ${ }^{77}$

(i)

$$
\text { Orally }
$$

Divorce may be effected orally in explicit terms (seerah). Where the word "talaq" is used explicitly, the marriage is terminated, whether or not the husband had the necessary intention to terminate the marriage. ${ }^{78}$ Examples of explicit terms would be "I talaq you" or "I divorce you".

Alternatively, kinaayah (ambiguous terms) may be used. This is where the husband uses other terms beside the word "talaq" to convey his intention to terminate the marriage. When terms other than the word "talaq" are used, it is important to establish the intention of the husband - that is, whether or not he intended to end the marriage. Examples of ambiguous terms would be "I hereby set you free", "Begin your iddah" or "You are no more my wife from this moment forward".

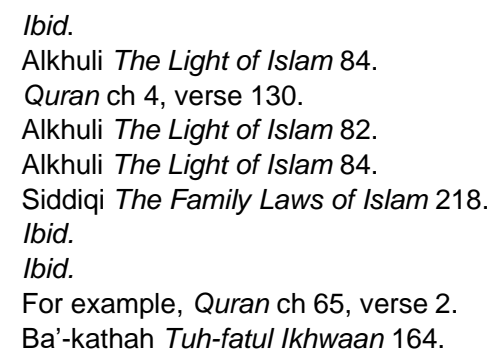




\section{(ii) Writing}

A marriage is similarly terminated if the talaq is written down. ${ }^{79}$ The wording must be clear and unambiguous and must convey the meaning that the marriage is being terminated. ${ }^{80}$ A dispute may arise as to the authenticity of the author of the divorce later. In this case, it must be proved that the husband is the person who wrote the letter with the intention of terminating the marriage. ${ }^{81}$

Whether the divorce is effected orally or in writing, the words uttered or written must convey the intention that the marriage is being dissolved. ${ }^{82}$ Therefore, where the divorce is issued under duress, or when the husband becomes mentally ill, the marriage is not dissolved and the divorce does not become effective. ${ }^{83}$ However, where the husband utters the word "talaq" in jest or playfully to his wife, the marriage will be deemed to be dissolved. ${ }^{84}$ This is the case, despite the fact that there was no intention on the part of the husband to terminate the marriage. ${ }^{85}$

The four schools of Islamic jurisprudence agree that the divorce of an unconscious person who is in that condition for a reason other than intoxication is null and void. ${ }^{86}$ They are also unanimous that the uttering of the word talaq while asleep does not result in the termination of a marriage. ${ }^{87}$

Islam prohibits the intake of any intoxicating substances such as drugs and alcohol. ${ }^{88}$ In the event that the husband voluntarily or willingly ingests an intoxicating substance that affects his powers of reasoning, and he pronounces a talaq while in this condition, the marriage is terminated. ${ }^{89}$ However, if the husband's power of reasoning is affected through non-sinful means - for example, through sickness or mental illness and he pronounces a talaq while so afflicted - the talaq will not be valid. ${ }^{90}$

\section{Restrictions on divorce}

Because Islam discourages divorce, certain restrictions have been placed on the spouse's right to seek a divorce. Alkhuli sets out the restrictions on divorce as follows: ${ }^{91}$

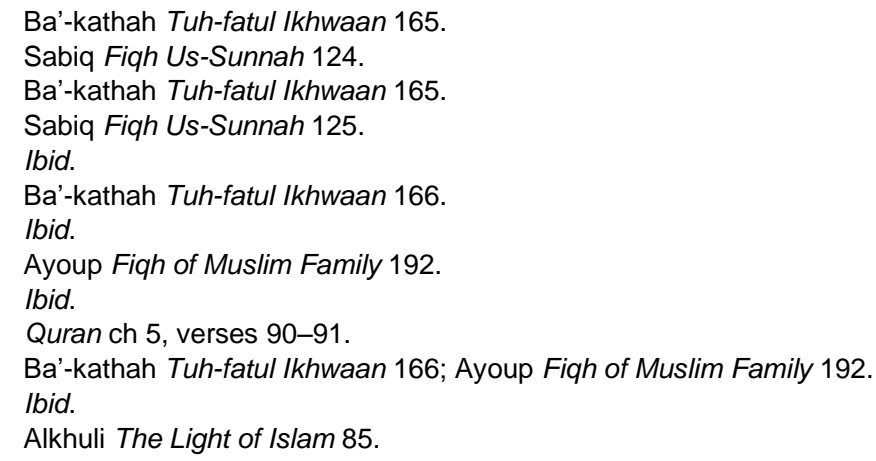


(i) The husband is not allowed to divorce his wife during the period she is menstruating. The reason for this restriction is that sexual intercourse is prohibited during this period, and the abstinence of sexual relations may cause cold relations between the husband and wife. This restriction on divorce therefore seeks to ensure that the husband is not merely seeking divorce because he is deprived of sexual intercourse.

(ii) Before a divorce can take place, the spouses must submit themselves to mediation. It is only upon the failure of such reconciliation attempts by two judges that the spouses would be allowed to proceed with a divorce.

(iii) Where a divorce is instituted, a waiting period (iddah) of three months (that is, three menstrual cycles) after the divorce must be observed by the wife. In the case of a pregnant woman, the waiting period is extended until the birth of the child. During the iddah period, the woman is prohibited from entering into marriage with a third party but can remarry her first husband. The compulsory waiting period provides both parties with an opportunity to reconsider the divorce and to remarry each other if they wish to do so.

(iv) The husband is prohibited from evicting the wife from the marital home once the divorce takes place. The wife may remain in the marital home for the duration of the iddah period.

(v) Both spouses are encouraged to remarry each other during and after the waiting period unless an irrevocable divorce has taken place. See (vii) below for the position of remarriage where the divorce is irrevocable.

(vi) In the case of a revocable divorce, the spouses are presented with two opportunities to remarry each other, after the first and second divorce has been issued.

(vii) Where a third divorce is issued, the divorce is irrevocable, and the wife is prohibited from remarrying her first husband, unless she has entered into a marriage with a third party and this marriage is terminated either through death or divorce.

\section{Number of talaq}

Islamic law only permits a man to divorce his wife in three separate and distinct periods, usually three-monthly courses. ${ }^{92}$ During these periods, the parties may try to reconcile, but if this proves to be unsuccessful, the divorce becomes effective after the lapse of the third period. ${ }^{93}$ In other words, in Islam, the husband possesses the power of three talaq, which need not all be given in order for the marriage to be terminated. ${ }^{94}$ For example, if the husband pronounces one talaq, and the wife completes her three-month period of iddah as required, the marriage is deemed to be terminated. However, if the parties wish to remarry each other after the iddah period they may do so, but the husband now only has two talaq. If the husband

\footnotetext{
Siddiqi The Family Laws of Islam 219.

Doi Shari'ah: The Islamic Law 173.

94 Ba'-kathah Tuh-fatul Ikhwaan 167.
} 
thereafter issues her with another two talaq, ${ }^{95}$ he has used up all his rights of talaq. If he now wishes to remarry his ex-wife, he would only be allowed to do so once she has entered into a marriage with a third party, consummation has occurred, and the subsequent marriage has been properly terminated. ${ }^{96}$

\section{Types of talaq}

A divorce initiated by the husband can be effected in one of two ways namely, the talaq al-sunna or the talaq al-bid'a. ${ }^{97}$

\section{Talaq al-sunna}

This method of divorce is recommended by Islamic law, and is in accordance with the Quran and the traditions of Prophet Mohammed (PBUH). ${ }^{98}$ In terms of this method of divorce, the husband must pronounce only one talaq or repudiation, during a period when the wife is in a state of purity. ${ }^{99}$ The underlying purpose for these conditions is to prevent the permanent termination of the marriage. ${ }^{100}$ These conditions also allow the husband to revoke the talaq or repudiation when better sense prevails, especially when the repudiation has been issued in a hasty and rash manner without proper consideration being given. ${ }^{101}$ During this period of separation, after the announcement of a talaq, the marriage continues to subsist between the parties. ${ }^{102}$ Where the parties reconcile during the wife's iddah period, there is no need for a new marriage contract to be concluded. ${ }^{103}$ However, if the husband has issued one or even two talaq, and he abstains from sexual intercourse with his wife, and no reconciliation tales place during the period of iddah, a complete cessation of the marital rights and duties between the spouses takes place. ${ }^{104}$ Should the spouses then wish to reconcile, a new contract of marriage would be required and the parties need to agree upon a new dower. ${ }^{105}$ Where the husband has issued one talaq and the parties decide not to reconcile after the expiry of the period of iddah, the wife is allowed to enter into a marriage with a third party, without him having to issue the other two talaqs. ${ }^{106}$

A distinction should be drawn between revocable and irrevocable divorces. ${ }^{107}$ The method of divorce described above is an example of a revocable divorce (raj'i). A talaq al-raji becomes effective only at the end of the waiting period (iddah) that starts after the first or second "divorce" is

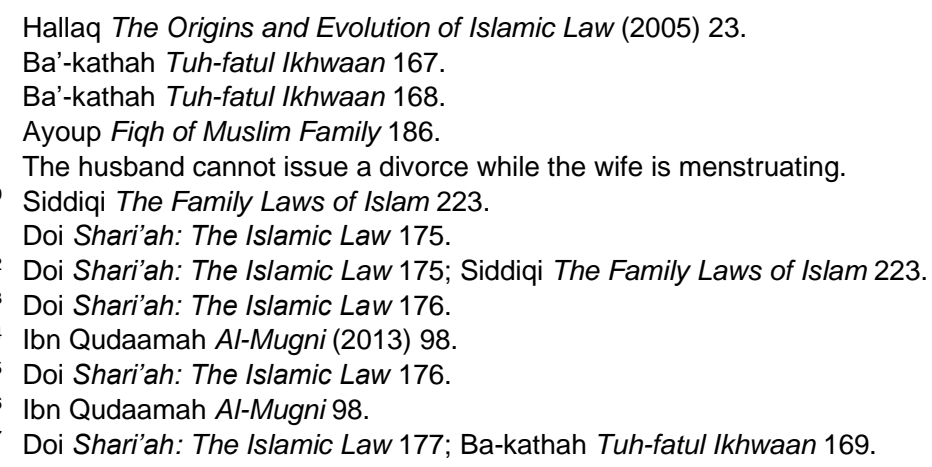


pronounced. ${ }^{108}$ During the waiting period, the woman remains the legal wife of the husband, and the husband is under an obligation to support his wife financially. ${ }^{109}$ While the parties are still in a position to reconcile and resume their marital relationship, a divorce with the possibility of reconciliation is allowed only twice. ${ }^{110}$ Thereafter, the parties must make a final decision to either dissolve the marriage permanently, or continue with the marriage. ${ }^{11}$

An irrevocable divorce (ba'in) is a divorce where the husband has made all three pronouncements. ${ }^{112}$ In this instance, the marriage is dissolved with immediate effect. ${ }^{113}$ When the husband pronounces the third talaq, it becomes a talaq al-ba'in, severing the marital rights and duties between the spouses. ${ }^{114}$ This means that the parties cannot enter into a marriage unless the former wife marries a third person and the latter voluntarily divorces her. ${ }^{115}$

\section{(ii) Talaq al-bid'a}

This second method to effect a divorce is not in accordance with the rules laid down by prophetic tradition, and is known as talaq al-bid'a or the innovated divorce. ${ }^{116}$ This method of divorce is not recommended, as the divorce becomes irrevocable as soon as it is pronounced. ${ }^{117}$ In terms of this method of divorce, the husband issues or conveys all three of the divorces in writing or orally in one sitting. ${ }^{118}$ Where the husband exercises his right of repudiation on three successive occasions as stated in the example, the divorce becomes irrevocable. ${ }^{119}$ Once the divorce becomes irrevocable, the parties are absolutely forbidden to remarry each other, as an irrevocable divorce severs the marital ties forever, unless the wife marries a third party and divorces the latter. ${ }^{120}$ After the termination of the marriage with the third party, the wife is allowed to remarry her first husband.

\section{(iii) Khula}

Khula can be defined as the termination of a marriage by the husband uttering the words "talaq" or "khula", and whereby he accepts compensation for freeing his wife from the marriage. ${ }^{121}$ The spouses can agree on any

\footnotetext{
108 Ibid.

109 Doi Shari'ah: The Islamic Law 176; Al-Fawzaan Al-Mulakhkhas Al-Fiqhi vol 2 (2001) 317.

110 Ibid.

111 Quran ch 2, verse 229.

112 Sabiq Fiqh Us-Sunnah 149

113 Ibid.

114 Doi Shari'ah: The Islamic Law 178

115 Sabiq Fiqh Us-Sunnah 145178 and 363; Quran ch 2, verse 230.

116 This divorce is commonly known as the "three-in-one", "triple" or instant divorce.

117 Doi Shari'ah: The Islamic Law 179.

118 Siddiqi The Family Laws of Islam 224.

119 Cachalia Future of Muslim Family Law in South Africa (1991) 69.

120 Bulbulia "Women's Rights and Marital Status: Are We Moving Closer to Islamic Law?" 1983 De Rebus 431432.

121 Ba'-kathah Tuh-fatul Ikhwaan 171; Siddiqi The Family Laws of Islam 230; Al-Misri and Keller Reliance of the Traveller: A Classic Manual of Islamic Sacred Law (2008) 562.
} 
amount of compensation, but it must be a fixed amount and it must have economic value. ${ }^{122}$ However, the amount of compensation paid by the wife must not exceed that which she received as dower. ${ }^{123}$ Furthermore, the parties have to agree on all the aspects of the contract in respect of the khula. The wife can use this method of divorce where she has suffered cruelty and abuse at the hands of her husband or where the husband has deserted her. ${ }^{124}$

In addition to the reasons cited above, the wife can also apply for a khula where she has an aversion to the physical appearance of her husband. ${ }^{125}$

The effect of a khula is that the divorce is rendered irrevocable and should therefore be resorted to only in extreme circumstances. ${ }^{126}$ The fact that a marriage dissolved by khula renders the divorce irrevocable means that the husband forfeits his right to reconcile with his wife. ${ }^{127}$ However, the parties can still remarry each other if they mutually agree to do so. ${ }^{128}$ The general rule in respect of khula is that all the conditions and restrictions applicable to talaq apply similarly to khula. ${ }^{129}$

\section{(iv) Divorce by mutual agreement (mubara'ah)}

In certain circumstances, the wife might not be in a financial position to pay the husband compensation, as required when the marriage is terminated by khula. ${ }^{130}$ The spouses to the marriage can, however, still dissolve the marriage if they mutually agree to do so. ${ }^{131}$ Where the husband makes an offer for a mutually agreed divorce, he may not withdraw his offer before the wife has given him an answer. ${ }^{132}$ Should the wife accept the offer for a mutually agreed divorce, the divorce is effective immediately. ${ }^{133}$ In contrast, if the wife makes the initial offer of a mutually agreed divorce, she is entitled to withdraw the offer at any time before acceptance by the husband. ${ }^{134}$

\section{( $v)$}

$$
\text { Judicial divorce (tafriq) }
$$

Islam makes provision for the pronouncement of a divorce by judicial intervention. ${ }^{135}$ This is where an Islamic court arbitrates the marital dispute

\footnotetext{
122 Ba'-kathah Tuh-fatul lkhwaan 171.

123 Doi Women in Shari'ah 96.

124 Doi Women in Shari'ah 96. See also the discussion of Faskh below.

25 Siddiqi The Family Laws of Islam 232.

126 Doi Women in Shari'ah 98.

127 Doi Shari'ah: The Islamic Law 194

28 Doi Women in Shari'ah 98

29 Siddiqi The Family Laws of Islam 232.

130 Schacht An Introduction to Islamic Law (1964) 164; Fyzee Outlines of Mohammadan Law (1974) 155.

131 Doi Women in Islam 97.

132 Esposito and DeLong-Bas Women in Muslim Family Law (2001) 32; Rautenbach and Bekker Introduction to Legal Pluralism 379.

133 Fyzee Outlines of Mohammadan Law 155.

134 Rautenbach and Bekker Introduction to Legal Pluralism 379.

135 Doi Shariah: The Islamic Law 170-172; Sabiq Figh Us-Sunnah 51.
} 
and pronounces a divorce. ${ }^{136}$ This is a method of divorce by judicial separation. ${ }^{137}$ Either the husband or the wife can institute an action for judicial separation. The two methods for judicial divorce are known as li'an and faskh.

(1) Li'an

False accusations of adultery and fornication, especially against chaste persons, are strictly prohibited in terms of Shari'ah. ${ }^{138}$ It is therefore incumbent upon the person who accuses another of such immoral misconduct to produce four witnesses who are able to provide eye-witness accounts of the misconduct in question. ${ }^{139}$ Where the husband levels such accusations ${ }^{140}$ and has no witnesses to attest to his accusations, and the wife furthermore denies his accusations, li'an will ensue. ${ }^{141}$ In other words, li'an or mutual imprecation brings about separation between the husband and wife when one of the spouses utters four oaths and one curse upon themselves. ${ }^{142}$ The oaths are uttered to show the person's own truthfulness. ${ }^{143}$

Where the husband, for example, accuses his wife of committing adultery, the spouses have to appear before a Qadi (judge), and the husband has to repeat under oath four times that his accusation bears the truth. ${ }^{144}$ On the fifth time, the husband invokes the curse of Allah if his accusation is false. ${ }^{145}$ The wife in turn has to repeat under oath four times that the husband's accusation is false. ${ }^{146}$ She is also required to invoke the curse of Allah. ${ }^{147}$ Where both spouses have taken these oaths, the Qadi will issue an order that the parties be separated and the marriage is thereby annulled. ${ }^{148}$ The parties are barred from ever remarrying each other. ${ }^{149}$

However, if the husband refuses to take these oaths after making these accusations against his wife, he will be punished. ${ }^{150}$ Similarly, punishment will be meted out to the husband if he chooses to withdraw during the course of taking the oaths. ${ }^{151}$ Where the wife refuses to take the required oath, and the husband has already taken the oaths, she invites upon herself the punishment for adultery. Li'an differs vastly from the situation where the

136 Rautenbach and Bekker Introduction to Legal Pluralism 379. In South Africa, there are no Islamic courts, and the parties in this case would approach the local Ulama or Judicial Council for a pronouncement of divorce.

137 Nasir The Status of Women Under Islamic Law 134.

138 Alkhuli The Light of Islam 106.

139 Ba'-kathah Tuh-fatul lkhwaan 172.

140 For example, the husband can accuse the wife of adultery, or he can deny that he is the father of the child, or alternatively he can deny that she is pregnant by him.

141 Doi Shari'ah: The Islamic Law 188.

142 Ba'-kathah Tuh-fatul lkhwaan 172.

143 Quran ch 24, verse 6.

144 Ba'-kathah Tuh-fatul lkhwaan 173.

145 Ibid.

146 Doi Shari'ah: The Islamic Law 189.

147 Ibid.

148 Ba'-kathah Tuh-fatul Ikhwaan 174.

149 Ba'-kathah Tuh-fatul Ikhwaan 175.

150 The punishment meted out to the husband is 80 lashes.

151 Ba'-kathah Tuh-fatul Ikhwaan 175. 
marriage is terminated through divorce, because even where the divorce is irrevocable, the spouses may remarry each other after the wife has entered into a marriage with a third party, and such marriage is dissolved at a later stage. ${ }^{152}$ Where the marriage is dissolved by li'an, the spouses are prohibited from marrying each other forever.

(2) Faskh

The literal meaning of the term faskh is "to annul a deed" or to "rescind a bargain". 153 The definition of faskh as it pertains to a marriage is the annulment or abrogation of the contract of marriage by the Qadi at the instigation of the wife. ${ }^{154}$ Faskh is the only method by which a wife can obtain a divorce without the husband's consent and participation. ${ }^{155}$ The marriage will be annulled if the Qadi is satisfied that the wife is prejudiced by the marriage. ${ }^{156}$

Where the wife wishes to apply for a faskh, this may be done on one of the following grounds: injury/discord; failure to maintain; defect on the part of the husband; husband's absence sine causa or imprisonment; and cruelty or incompatibility. ${ }^{157}$

\section{(vi) Other grounds for terminating a marriage}

(1) Apostasy: The marriage is automatically and immediately annulled where the husband turns apostate and renounces Islam. ${ }^{158}$

(2) Elaa: This is the temporary separation between husband and wife, where the husband in anger takes an oath that he will refrain from having sexual intercourse with his wife for a period of four months. ${ }^{159}$ The marriage would be dissolved when the husband does not resume sexual relations with his wife at the end of the four-month period. ${ }^{160}$

Once the four-month period has lapsed, the wife has the right to demand that her husband resume sexual relations with her, or else he must talaq her. ${ }^{161}$ Furthermore, once the four-month period has lapsed, the spouses are required to remarry each other if they wish to continue to live together as husband and wife. ${ }^{162}$ Where the husband, however, has sexual intercourse with his wife before the expiry of the four-month period, the marriage remains intact, but the husband has to give compensation for breaching the oath. ${ }^{163}$

\footnotetext{
52 Ayoup Fiqh of Muslim Family 320.

53 Doi Shari'ah: The Islamic Law 171

154 Doi Women in the Shari'ah 90.

Nasir The Islamic Law of Personal Status (2002) 120-133.

156 Doi Women in the Shari'ah 90.

57 Moodley 2001 Codicillus 89.

58 Siddiqi The Family Laws of Islam 237; Quran ch 60, verse 10.

159 Siddiqi The Family Laws of Islam 238; Ba'-kathah Tuh-fatul Ikhwaan 170.

160 Quran ch 2, verses 226-227.

161 Ba'-kathah Tuh-fatul Ikhwaan 171.

162 Sidiqi The Family Laws of Islam 238.

163 Ba'-kathah Tuh-fatul Ikhwaan 170.
} 


\section{Iddah}

In terms of Islamic law, iddah can be defined as a compulsory period of waiting imposed on a woman after the death of her husband or on her divorce. During this time, the wife is prohibited from remarriage. ${ }^{164}$ The reasons given by Shari'ah for the compulsory period of waiting are fourfold - namely, it provides the spouses with an opportunity to reconsider whether the divorce should be revoked or made final; it allows the parties to determine whether or not the wife is pregnant by her husband so that there may be no confusion as to the paternity of the child; it provides the widow with a mourning period where the marriage is dissolved through the death of the husband ${ }^{165}$ and lastly, it provides the wife with nafaqah for a definite period after the marriage ends. ${ }^{166}$

\section{(i) Different kinds of iddah}

The various kinds of iddah can be listed as: the iddah of women who menstruate; the iddah of a mustahaadhah; ${ }^{167}$ the iddah of women who have passed the age of menstruation; the iddah of the widow; and the iddah of a pregnant woman. ${ }^{168}$

\section{(ii) The rights of the woman in iddah}

During the period of iddah, the wife is prohibited from remarriage. ${ }^{169}$ She is entitled to remain in the marital home for the duration of the iddah, whether the marriage has been terminated by talaq, annulment or death of the husband. ${ }^{170}$ The husband cannot evict her from the marital home. ${ }^{171}$ Similarly, no one is allowed to evict the wife from the marital home in the event of the death of her husband. ${ }^{172}$ Where the deceased husband died without providing the widow with a place to live, the duty to provide suitable lodgings for her falls on the heirs of the deceased. ${ }^{173}$

164 Doi Shari'ah: The Islamic Law 198; Quran ch 2, verse 228.

165 Sabiq Fiqh us-Sunnah: Doctrine of Sunnah of the Holy Prophet (1989) 198208.

166 Siddiqi The Family Laws of Islam 220-221. It must be noted that the iddah period for the divorcée is three months or three menstrual cycles. The iddah period for the widow is four months and ten days.

167 Mustahaadhah refers to a woman who experiences menstruation that continues for longer than the normal period of menstruation, or to a person who experiences irregular cycles of menstruation.

168 The rules pertaining to the different kinds of iddah are discussed in Ba'-kathah Tuh-fatul Ikhwaan 174-177; Siddiqi The Family Laws of Islam 220; Sabiq Fiqh Us-sunnah 201; AlMisri et al Reliance of a Traveller: A Classic Manual of Islamic Sacred Law 571.

169 Doi Shari'ah: The Islamic Law 203.

170 Ibid.

171 Ba'-kathah Tuh-fatul Ikhwaan 177; Al-Misri et al Reliance of a Traveller: A Classic Manual of Islamic Sacred Law 569.

172 Ibid.

173 Ibid. 
A woman in a state of iddah is not allowed to leave her house to attend social functions, visit family and friends or for recreation. ${ }^{174}$ The only time such a woman can leave her home is for necessity - for example, to purchase food or to go to work. ${ }^{175}$

\section{South African law}

As a result of the enactment of the Divorce Act, ${ }^{176}$ the law relating to divorce was changed to a no-fault divorce system, as far as the grounds for divorce were concerned.177 Although divorce is no longer fault-based, the misconduct of the parties is still a factor that is taken into consideration with regard to the patrimonial consequences of divorce. ${ }^{178}$

\section{Definition of divorce}

The Divorce Act does not provide a definition of the term "divorce" but merely refers to the term "divorce action" as being "action by which an application is made for a decree of divorce or other relief in connection with the divorce". ${ }^{179}$ The ordinary meaning of divorce as defined by the Oxford Dictionary as the "legal ending of a marriage". ${ }^{180}$ The Divorce Act is gender neutral and either the husband or the wife can institute an action for divorce on one of the grounds of divorce as stipulated in the Divorce Act.

\section{Pre-divorce procedure}

Although the spouses are encouraged to institute an action for divorce as a last resort, the Divorce Act, unlike Shari'ah, does not prescribe any predivorce procedure. In other words, while the spouses can be encouraged to embark on mediation with a view to reconciliation, there is no legal duty on them to do so. The judiciary has, however, emphasised that mediation should be preferred over litigation in family disputes. ${ }^{181}$

\section{Grounds for divorce}

Previously, the four recognised grounds for divorce were adultery, malicious desertion, incurable mental illness lasting seven years, and lastly, imprisonment for at least five years after having been declared an habitual criminal. ${ }^{182}$ The Divorce Act replaced these grounds of divorce and

174 Ayoup Fiqh of Muslim Family 331-332.

175 Ba'-kathah Tuh-fatul Ikhwaan 177-178.

17670 of 1979.

177 Barratt et al Law of Persons and the Family 334.

178 Heaton and Kruger South African Family Law 130.

179 S 1 of the Divorce Act 70 of 1979.

180 Hawkins, Delahunty and McDonald Oxford Mini School Dictionary (2002) 191.

181 MB v NB 2010 (3) SA 220 (GSI); FS v JJ 2011 (3) SA 126 (SCA).

182 Adultery and malicious desertion are common-law grounds of divorce. In 1935, the Divorce Laws Amendment Act 32 of 1935 introduced incurable mental illness and imprisonment of the defendant spouse after being declared an habitual criminal as grounds of divorce. 
introduced irretrievable breakdown of the marriage ${ }^{183}$ and mental illness, as well as continuous unconsciousness, ${ }^{184}$ as grounds of divorce. The widening and relaxing of the grounds of divorce have resulted in South Africa being described as one of the easiest countries in the world in which to obtain a divorce, as a divorce is essentially available on demand. ${ }^{185}$

Section 3 of the Divorce Act provides for the following no-fault grounds of divorce: irretrievable breakdown of the marriage; mental illness; and continuous unconsciousness.

\section{(i) Irretrievable breakdown of the marriage}

When a spouse cites that the marriage has broken down irretrievably as the ground upon which the divorce is sought, the spouse has to prove the following: ${ }^{186}$

(1) the marriage relationship has disintegrated to the point where it is no longer a normal marriage relationship; and

(2) there is no reasonable prospect of the restoration of a normal marriage relationship between the spouses in the future.

In other words, the consortium omnis vitae between the spouses must have been either destroyed or violated. ${ }^{187}$ In order to determine whether this has indeed occurred, the court employs a subjective and an objective approach. ${ }^{188} \mathrm{~A}$ combination of the subjective and objective approach dictates that the court will consider whether the marriage has broken down irretrievably from the point of view of the spouses concerned, taking into account the fact that the plaintiff is suing for divorce while also taking into account its own interpretation of the facts and circumstances of the marriage, by paying attention to the history and present state of the marriage. ${ }^{189}$ Where both spouses indicate that they no longer wish to be married to each other, the courts will conclude that the marriage has broken down irretrievably. ${ }^{190}$ This is the position even where one of the spouses does not want to get divorced and wants to save the marriage. ${ }^{191}$ Where the other spouse is determined to end the marriage, the court will conclude that the marriage has broken down irretrievably. ${ }^{192}$

Section 4(2) provides certain guidelines to assist the court in its determination as to whether the marriage has broken down irretrievably. ${ }^{193}$

\footnotetext{
$183 \mathrm{~S} 4(1)$ of the Divorce Act 70 of 1979.

184 S 5(1) and (2) of the Divorce Act 70 of 1979.

185 Hawkey "Africans Catch the Divorce Bug" (2009-11-29) Sunday Times Live.

$186 S$ 4(1) of the Divorce Act 70 of 1979.

187 Schwartz v Schwartz 1984 (4) SA 467 (A); Naidoo v Naidoo 1985 (1) SA 366 (T).

188 Schwartz v Schwartz supra; Naidoo v Naidoo supra; Swart v Swart 1980 (4) SA 364 (O).

189 Ibid.

190 Singh $v$ Singh 1983 (1) SA 781 (C) 786D.

191 Barratt et al Law of Persons and the Family 337.

192 Ibid.

193 For example, the parties have not lived together as husband and wife for a period of one year, or the defendant has committed adultery, and the plaintiff finds it irreconcilable to continue with the marriage.
} 


\section{(ii) Mental illness or continuous unconsciousness}

The special grounds for divorce in section 5(1) and (2) of the Divorce Act are very detailed, narrow and precise, and require the evidence of medical experts to be cited as grounds for divorce. The reason for these stringent requirements is that a spouse who is mentally ill, or in a state of continuous unconsciousness, is particularly vulnerable. ${ }^{194}$

A question that arises is whether a spouse instituting divorce proceedings must cite the grounds set out in section 4 , or those in section 5 , where the defendant spouse is for example, mentally ill. From court decisions, ${ }^{195}$ it is clear that where the defendant spouse is, for example, mentally ill, the plaintiff can decide whether to institute a divorce in terms of section 4 or section 5. By citing irretrievable breakdown of the marriage as the ground for divorce, the plaintiff can escape the stringent requirements set out in terms of section 5 .

\section{Forms of divorce}

From the definition of the term "divorce", it can be deduced that a civil marriage can only be dissolved by instituting a divorce action in a court of law. The spouses, therefore, cannot of their own accord, either orally or in writing, terminate their marriage without involving the courts.

\section{Restrictions on divorce}

As the use of the word "may" in sections 3, 4 and 5 of the Divorce Act implies that a court can refuse to grant a divorce, even if one of the grounds of divorce has been proved, the question arises as to whether a court has a discretion to grant or refuse a divorce. ${ }^{196}$ If the court is of the opinion that there is a reasonable prospect that the consortium omnis vitae between the spouses can be restored so that the spouses can resume a normal marriage relationship, the court will not have the power to grant a divorce, as irretrievable breakdown is a requirement for divorce in terms of section 4 of the Divorce Act. ${ }^{197}$ In this respect, section 4(3) makes provision for the court to postpone divorce proceedings if it appears to the court that there is a reasonable possibility that the spouses may become reconciled through marriage counselling or further reflection. In contrast, if the court is satisfied that the marriage has broken down irretrievably, and there is no reasonable prospect of restoring a normal marriage relationship between the spouses, the court is obliged to grant the divorce. ${ }^{198}$

Furthermore, in terms of section 6 of the Divorce Act, the court can also refuse to, and in fact cannot, grant a decree of divorce until the court is

$194 \mathrm{~S} \mathrm{5(3)}$ and (4) of the Divorce Act 70 of 1979. Where a divorce is sought on the grounds of s 5(1) or (2), an application for the forfeiture order cannot be made.

195 Smit v Smit 1982 (4) SA 34 (O); Ott v Raubenheimer NO 1985 (2) SA 851 (O); Dickson v Dickson 1981 (3) SA 856 (W).

196 Schwartz v Schwartz supra 474.

197 Ibid.

198 Ibid. 
satisfied that the provisions with regard to the welfare of any minor children are satisfactory or are the best that can be effected in the circumstances.

Section $5 \mathrm{~A}$ regulates the position where the parties have concluded a religious marriage in addition to a civil marriage. Section $5 \mathrm{~A}$ provides that a court can refuse to grant a divorce until a spouse who has the power to procure a religious divorce takes the necessary steps to do so. Although section $5 \mathrm{~A}$ was originally inserted to provide relief for Jewish wives, section $5 \mathrm{~A}$ is not limited to the Jewish faith and can be used by anyone practising other religions in appropriate circumstances, including adherents of Islam. ${ }^{199}$

\section{The law of England and Wales}

Initially, when the dissolution of a marriage by divorce was introduced in 1857 , adultery was the only ground for divorce. ${ }^{200}$ This position prevailed until 1937 when three additional grounds of divorce were added - namely, cruelty, desertion and incurable insanity. ${ }^{201}$ In 1969, the Divorce Reform Act provided that irretrievable breakdown of the marriage was the sole ground for divorce. ${ }^{202}$ The law regulating divorce law has been consolidated in the Matrimonial Causes Act 1973.203

\section{Definition of divorce}

A divorce brings an end to a legal relationship that exists between married spouses; when a decree of absolute of divorce is granted, this terminates the legal rights and obligations that the parties owe each other during the subsistence of the marriage. ${ }^{204}$

\section{Pre-divorce procedure}

Section 6(1) of the Matrimonial Causes Act 1973 provides that if a petitioner consults a solicitor with regard to the institution of divorce action, the solicitor is required to certify whether the possibility of reconciliation has been discussed, and furthermore, whether the names and addresses of organisations or people that can assist the spouses have been provided. The aim of section $6(1)$ is to ensure that the solicitor reflects carefully on whether the parties ought to consider reconciliation. ${ }^{205}$

99 Amar v Amar 1999 (3) SA 604 (W).

200 Divorce and Matrimonial Causes Act 1857.

201 Matrimonial Causes Act 1937.

202 Burton Family Law 77.

203 Douglas An Introduction to Family Law (2004) 177.

204 All decrees of divorce are, in the first instance, decrees nisi that do not legally terminate the marriage. However, a decree nisi may be made absolute, on the application of a party in whose favour it was granted, six weeks after the decree was pronounced. The party against whom the decree was granted may also make an application after three months for it to be made absolute. The time period between the decree nisi and the decree absolute is often used to negotiate the financial settlements and other consequences that flow from the dissolution of a marriage (Herring Family Law 110).

205 Herring Family Law 118. 


\section{З 33 Grounds for divorce}

As indicated above, the Divorce Reform Act 1969 provides that the sole ground for divorce is that the marriage between the spouses must have broken down irretrievably. To establish whether the marriage has broken down irretrievably, one of five facts has to be proved - namely adultery, unreasonable behaviour, desertion, living apart for two years with the respondent's consent, or living apart for five years. ${ }^{206}$

\section{(i) Adultery}

The definition ascribed to "adultery" is the voluntary sexual intercourse between a married person and a person of the opposite sex, whether married or not, who is not the married person's spouse. ${ }^{207}$ The marriage is deemed to have broken down irretrievably where one spouse has committed adultery and the other spouse finds it intolerable to live with the guilty spouse. ${ }^{208}$ The spouse applying for the divorce (petitioner) cannot rely on his or her own adultery. ${ }^{209}$ In terms of section 1(2)(a) of the Matrimonial Causes Act 1973, the petitioner is required to prove that the other spouse (respondent) had committed adultery, and is required to demonstrate that the petitioner finds it intolerable to live with the respondent. The courts have, however, held that, despite the presence of two elements - namely, adultery and the fact that the innocent spouse finds it intolerable to live with the guilty spouse - the latter element does not necessarily have to be linked to the first. ${ }^{210}$ The fact that one spouse finds it intolerable to live with the guilty spouse is not necessarily attributed to adultery. ${ }^{211}$

The spouses are barred from instituting an action for divorce on the ground of adultery where the spouses have continued to live together for six months or more (whether continuously or in an aggregate of shorter periods) after the discovery of the adultery. ${ }^{212}$ It is the discovery of the adultery, and not the date of its commission, that is used to calculate the six months, and it is therefore still possible to institute an action for divorce on the ground of an adultery that occurred many years ago, provided discovery thereof is within the time period prescribed in section 2(1). ${ }^{213}$

\section{(ii) Unreasonable behaviour}

Section $1(2)(b)^{214}$ provides that an irretrievable breakdown of the marriage can be inferred where one spouse behaves in such a manner that the other

\footnotetext{
206 Probert Family and Succession Law in England and Wales 106.

207 Burton Family Law 79.

208 S 1(2)(a) of the Matrimonial Causes Act 1973

209 Herring Family Law 111.

210 Cleary v Cleary and Hutton [1974] 1 W.L.R. 73; Carr v Carr [1974] 1 WLR 1534; [1974] 1 All ER 1193, CA

211 Goodrich v Goodrich [1971] 1 WLR 1142; [1971] 2 All ER 1340.

212 S 2(1) of the Matrimonial Causes Act 1973; Cretney, Mason and Bailey-Harris Principles of Family Law (2003) 281.

213 Burton Family Law 83.

214 Matrimonial Causes Act 1973.
} 
spouse can no longer reasonably be expected to live with the guilty spouse. The courts use objective and subjective tests to establish whether this is indeed the case. ${ }^{215}$ The central question that the courts are required to ask is whether any right-thinking person would come to the conclusion that one spouse behaved in such a manner that the other spouse cannot reasonably be expected to live with the guilty spouse, regard being had to all the circumstances and the character and personalities of the spouses. ${ }^{216}$ The modern approach to establishing what constitutes unreasonable behaviour is primarily concerned with assessing any conduct that is not trivial in nature, and considering the conduct objectively to establish the effect it has on the spouse petitioning for the divorce. ${ }^{217}$ Examples of behaviour that have been found to be sufficient for the petitioner to succeed with the application for divorce are violence; 218 insensitivity, lack of communication or excessive unsociability;219 bullying or constant criticism;220 financial irresponsibility or excessive financial restriction;221 emotional222 or sexual dissatisfaction, ${ }^{223}$ boredom and growing apart. ${ }^{224}$

\section{(iii) Desertion}

Where one spouse has deserted the other spouse for a continuous period of two years immediately prior to the institution of an action for divorce, it can be inferred that the marriage has broken down irretrievably. ${ }^{225}$ Despite the explicit reference to a continuous period of two years in section 1(2)(c), section 2(5) qualifies this by providing that periods of cohabitation totalling less than six months will not be taken into account towards the two-year period stipulated in section 1(2)(c).

Desertion comprises both a physical and mental dimension, as there must be both physical separation and the intention to desert. ${ }^{226}$ This requirement is deemed to be met even though the spouses continue to live in the same house, as long as they have established separate households. ${ }^{227}$

\footnotetext{
215 Livingstone-Stallard $v$ Livingstone-Stallard [1974] Fam. 47, which was adopted by the Court of Appeal in O'Neill v O'Neill [1975] 1 W.L.R. 118.

216 Buffery v Buffery [1980] 2 FLR 365; Livingstone-Stallard v Livingstone-Stallard supra 54; O'Neill v O'Neill supra.

217 Birch v Birch [1992] 1 FLR 564.

218 Bergin v Bergin [1983] 1 All ER 905.

219 Bannister v Bannister [1980] 10 Fam Law 240, CA.

220 Livingstone-Stallard $v$ Livingstone-Stallard supra.

221 Cartr-Fea v Carter-Fea [1987] Fam Law 131.

222 Pheasant $v$ Pheasant [1972] 2 WLR 353.

223 Dowden v Dowden [1977] 8 Fam Law 106.

224 Morgan v Morgan [1973] 117 SJ 223.

225 S 1(2)(c) of the Matrimonial Causes Act 1973; Cretney et al Principles of Family Law 288.

226 Le Brocq v Le Brocq [1964] W.L.R.1085.

227 Ibid.
} 


\section{(iv) Living apart for two years plus the respondent's consent}

In an attempt to reduce the animosity and bitterness that usually arise between spouses who are divorcing, there was a move away from faultbased divorce law with the introduction of this ground for divorce. ${ }^{228}$ To meet the requirements set out in this ground for divorce, either one of the spouses must leave the marital home or, where the spouses continue to live in the same house, they must have established separate households. ${ }^{229}$ The requisite "continuous" period of separation can be made up of shorter periods, provided the interludes of cohabitation do not exceed six months. ${ }^{230}$

Insofar as the consent requirement is concerned, only consent to the divorce and not to the separation is required. 231

\section{(v) Living apart for five years}

In terms of this ground for divorce, the spouses are required to live apart for a continuous period of five years immediately preceding the institution of the application for divorce. This was an innovation when divorce law was reformed in 1969, as for the first time a divorce was allowed against the wishes of the innocent spouse. ${ }^{232}$

\section{З3 4 Restrictions on divorce}

In order to encourage newly married spouses to give their marriage a chance, the law provides that they may not petition for a divorce during the first year of marriage. ${ }^{233}$ This is an absolute bar to which there are no exceptions. ${ }^{234}$

\section{Comparison}

Notwithstanding the fact that Islamic, South African and English law value the institution of marriage and attach importance thereto, all three legal systems acknowledge the necessity of terminating the marriage in certain circumstances. This is especially so as none of the three legal systems expects spouses to remain in a marriage where the marriage relationship is acrimonious and unhappy.

Besides this similarity, there are also fundamental differences between the laws relating to divorce in these three legal systems.

In terms of Islamic law, the right to divorce is the exclusive right of the

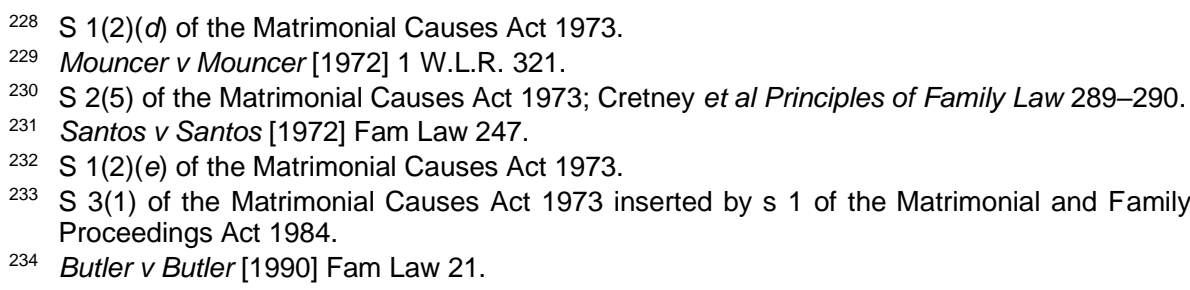


husband. Where a wife wants to terminate the marriage, special grounds have to be present in order for her to do so. A husband is also allowed to unilaterally issue a divorce without intervention from any religious authority. Where a wife wants to terminate the marriage, she has to approach the relevant religious authority in order to do so. Islamic law, therefore, differentiates between the dissolution of a marriage instituted by a husband and one instituted by a wife. On the other hand, where South African and English divorce law are concerned, both husband and wife have the same right to institute an action of divorce, based on the same grounds and the same rules.

Before parties can terminate their marriage, Islamic law makes it incumbent on the spouses to appoint two arbiters, one from the family of each spouse, in order to assist the spouses to reconcile. Although, in terms of English law, a solicitor is required to certify whether the possibility of reconciliation has been discussed, there is no legal duty on the parties to submit themselves to mediation. The same applies regarding the requirement that the solicitor give the spouses the names and addresses of organisations or people that can assist the spouses should they wish to reconcile. Parties married in terms of South African civil law cannot be compelled to mediate or arbitrate their dispute before instituting an action for divorce, although it is strongly encouraged.

Insofar as the grounds for divorce are concerned, there are vast differences between Islamic and South African law. In particular, in Islam, adultery is regarded as a ground for divorce. Islamic law also allows a spouse to institute an action for divorce where one spouse is chronically ill, impotent, sterile, serving life imprisonment, or is absent and his or her whereabouts are unknown. In contrast, when South African law shifted to no-fault divorce, adultery was relegated to a mere factor to be taken into consideration to determine whether or not the marriage has broken down irretrievably. In other words, adultery is no longer a ground for divorce. South African divorce law recognises the irretrievable breakdown of the marriage as well as mental illness and continuous unconsciousness as grounds for divorce. English law, on the other hand, only recognises one ground for divorce - namely, the irretrievable breakdown of the marriage. The fact that one spouse has committed adultery can be used to establish that the marriage has broken down irretrievably.

A fundamental difference between the legal systems is that, in terms of Islamic law, the husband is allowed to terminate the marriage in writing or orally, without court intervention. In contrast, where spouses are married in terms of South African or English law, an action for divorce must be instituted in a court of law. A divorce can, therefore, only be granted where a court legally terminates the marriage.

Despite the fact that in all three legal systems there are certain restrictions in place before a decree of divorce is granted, the restrictions encountered in Islamic law differ vastly from those found in South African and English law.

A divorce initiated in terms of Islamic law becomes effective immediately that is, the moment it is pronounced. This does, however, not mean that the divorce is finalised at this stage. The marriage may still remain valid. If the parties reconcile before the end of the three-month iddah period, there is no 
need for them to remarry, as the marriage remains intact. In contrast, when a civil court issues a decree of divorce, the divorce is finalised for all intents and purposes. In South African and English law, once an order of divorce is pronounced, the marriage is terminated, and should the parties wish to reconcile, they will have to conclude another marriage.

Lastly, for spouses married in terms of South African law, there is no period of iddah for the wife, irrespective of whether the marriage is terminated by death or divorce as is the case in Islamic law. In South African law, the parties can remarry as soon as the divorce is finalised.

These differences again highlight the dilemma of Muslims in South Africa, England and Wales as the law of divorce in terms of Islamic law differs vastly from that of South African and English law.

\section{ECONOMIC CONSEQUENCES OF DIVORCE}

\section{Islamic law}

The dissolution of a marriage has far-reaching economic implications for the spouses of a marriage. In respect of the dissolution of a marriage in terms of Islamic law, the following consequences warrant discussion - namely, the division of the matrimonial property, maintenance, the position of the dower and inheritance.

\section{Division of the matrimonial property}

The spouses retain sole rights of ownership and control over their individual property as a marriage concluded in terms of Islamic law is a non-sharing system unless the parties have entered into a marriage contract. ${ }^{235}$ Where a marriage contract has been entered into prior to the conclusion of the marriage, the matrimonial property will be divided according to the terms of the marriage contract. 236

\section{Maintenance (nafaqah) after the dissolution of the marriage}

The husband is obliged to maintain his wife during the subsistence of the marriage. ${ }^{237}$ Subject to certain conditions, this duty continues, even in the event of the marriage being dissolved by divorce. ${ }^{238}$

Where the divorce is revocable, the husband is still obliged to maintain the wife and provide her with accommodation, food, drink and clothing for the

235 Alkhuli The Light of Islam 72; Quran ch 5, verse 1. There is uncertainty whether the parties will use the marriage contract to enter into a matrimonial property regime that is contrary to the dictates of Islamic law.

236 Alkhuli The Light of Islam 72. The prospective spouses have the right to negotiate conditions that will apply to marriage provided these conditions are not contrary to the meaning of marriage. For example, the parties cannot agree to live separately.

237 Doi Shari'ah: The Islamic Law 204; Ayoup Fiqh of Muslim Family 351.

238 Doi Women in Shari'ah 108; Siddiqi The Family Laws of Islam 109; Quran ch 65, verse 6. 
period of three months after the divorce - the iddah or waiting period. ${ }^{239}$ The rationale is that the woman is still a wife as long as the iddah continues and she is, therefore, entitled to the same maintenance as another wife. ${ }^{240}$ Where the divorce is irrevocable, the wife is not entitled to maintenance. ${ }^{241}$ After the three-month iddah period has lapsed, the husband ceases to be responsible for the maintenance of his former wife, as they are regarded as strangers. ${ }^{242}$ It should be noted, however, that the wife may in certain instances not be entitled to maintenance during the iddah period. ${ }^{243}$

Where the wife is pregnant at the time of divorce, the husband has to maintain her for the entire duration of the pregnancy, as well as during the time that she is breastfeeding the child. ${ }^{244}$ The husband is therefore under an obligation to maintain his pregnant wife during the course of the pregnancy and, after the delivery of the baby, he is further obliged to pay his wife for breastfeeding the baby. ${ }^{245}$ However, after the delivery of the baby, he is not obliged to maintain his ex-wife. ${ }^{246}$

In Islamic law, the responsibility of the maintenance of the divorced woman reverts to her relatives: her son, or father, or other relations. ${ }^{247}$ As far as the former wife is concerned, as soon as the iddah period has expired, she no longer has a claim for maintenance against her former husband, although she can claim for child-minding services. ${ }^{248}$

At the time of divorce, the wife is entitled also to any unpaid maintenance due to her that accumulated during the course of the marriage, as this is a debt against the husband's estate that does not prescribe. ${ }^{249}$ The father, besides maintaining his children, is also responsible for the cost of childcare. ${ }^{250}$ Where the children are in the custody of the mother, their father is under an obligation to remunerate her for the childcare services that she renders by taking care of their children. ${ }^{251}$ The father or former husband must provide housing for her and the children born of the marriage. ${ }^{252}$

239 Quran ch 65, verse 6; Qasmi The Complete System of Divorce (2002) 217.

240 Al-Fawzaan Al-Mulakhkhas al-Fiqhi 317.

241 lbid.

242 Qasmi The Complete System of Divorce 223; Moosa and Karbanee "An Exploration of Mata'a Maintenance in Anticipation of the Recognition of Muslim Marriages in South Africa: (Re-)Opening a Veritable Pandora's Box" 20042 Law, Democracy and Development 269 with reference to the Quran ch 2, verse 223 and ch 65, verse 1 and 6.

243 Nasir The Status of Women Under Islamic Law 143.

244 Vahed Islamic Law (Shari'ah): An Introduction to the Principles of Islamic Law (2005) 32 with reference to Quran ch 65, verse 6. The breastfeeding may last for up to two years (Sakr Family Values in Islam (undated) 48); Quran Al-Talaaq 65:6.

245 Al-Mawsoo'ah al-Fiqhiyyah vol 17 (1983) 311.

246 Ibid.

247 Vahed Islamic Law 32; Qasmi The Complete System of Divorce 228; Sallie Maintenance and Child-Care According to Islamic Law (2001)105.

248 Doi Shari'ah: The Islamic Law 206; Denson and Carnelley "The Awarding of Post-Divorce Maintenance to a Muslim Ex-Wife and Children in the South African Courts: The Interaction between Divine and Secular Law" 2009 30(3) Obiter 679686.

249 Sallie Maintenance and Child-Care According to Islamic Law 43.

250 Ibid.

251 lbid.

252 Ibid. 
Furthermore, he has to provide the food and all other necessaries to ensure that his children are not left destitute and impoverished. ${ }^{253}$

\section{Position of dower on divorce}

When a marriage has been concluded without stipulating the dower and the spouses terminate the marriage before consummation takes place, there is no liability on the husband to make any payment of dower. ${ }^{254}$ However, the Quran recommends that the husband pay something to the wife according to his means and ability, as some harm has been done to her reputation due to the divorce. ${ }^{255}$

Where the amount of dower is stipulated and agreed upon before the marriage is concluded, and the divorce takes place before consummation of the marriage, the husband has to pay the wife half of the fixed amount.256

A woman who seeks to terminate her marriage by khula also has to pay back the whole or at least a portion of the dower she received from her husband. Where the marriage is dissolved after consummation has taken place, and the amount fixed as dower has not been paid by the husband, the wife is entitled to the full amount of dower. ${ }^{257}$

\section{Inheritance}

The termination of the marriage by divorce has certain legal implications on inheritance. Islam limits the power of testamentary disposition to one-third of the testator's estate, as the remaining two-thirds must be distributed among the heirs. ${ }^{258}$ Insofar as the spouses are concerned, they may inherit from each other if the divorce is revocable. ${ }^{259}$ In this instance, if either spouse dies during the period of iddah, the surviving spouse is entitled to inherit from the deceased. ${ }^{260}$ Where the divorce is revocable, the wife inherits a fourth of the deceased husband's estate, where the latter died without any offspring. ${ }^{261}$ Where the deceased husband dies leaving children, the wife inherits only an eighth of his estate. ${ }^{262}$ Where the husband dies leaving no children, but more than one widow, the surviving widows' collective share is one quarter. ${ }^{263}$ Where the deceased leaves children and more than one widow, their collective share is one-eighth. ${ }^{264}$ These rules are, however, subject to the condition that before the heirs inherit, all the deceased's debt,

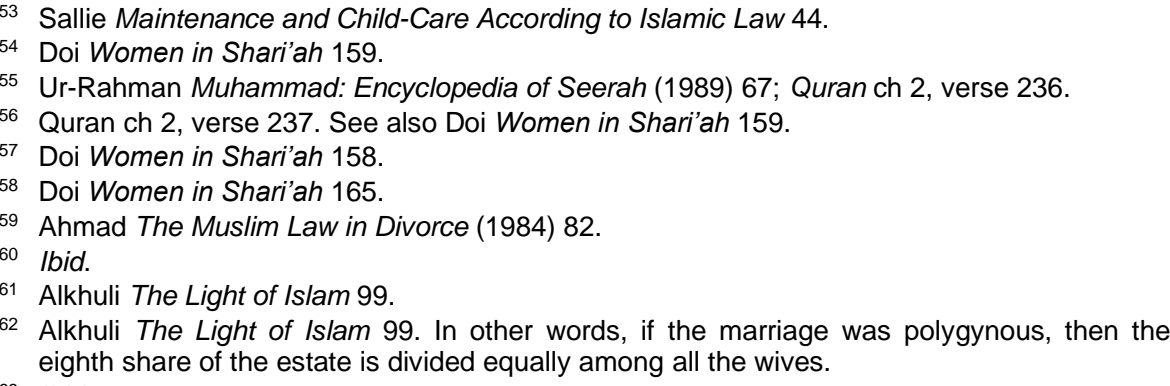


which includes funeral expenses, must first be settled and effect must be given to bequests and legacies. ${ }^{265}$ In the event of an irrevocable divorce, the spouses are not allowed to inherit from each other. ${ }^{266}$

\section{Pension-sharing}

As the spouses maintain completely separate estates during the subsistence of the marriage, they are not entitled to share each other's pension at divorce.

\section{South African law}

The most important economic consequences of divorce - namely, division of the spouses' marital property, maintenance matters between the spouses, the interests of the children born of the marriage ${ }^{267}$ and costs issues - are regulated by sections 6 to 10 of the Divorce Act. 268 Section 7(1) of the Divorce Act regulates the situation where the divorcing spouses enter into a settlement agreement that stipulates how the spouses' assets are to be divided, and for the payment of spousal maintenance. In terms of section 7(1), the court can make this settlement agreement an order of court. The settlement agreement in the majority of cases relates to matters concerning the division of the spouses' assets, the payment of spousal maintenance, and matters concerning access and contact with any minor children born of the marriage, but it can include any provision, provided that the provision is not illegal or contra bonos mores. ${ }^{269}$

Section 7(1) furthermore grants the court a discretion as to whether to incorporate the spouse's settlement agreement into the divorce order. As divorce proceedings are very costly and time consuming, it is often in the spouses' interest to enter into a settlement agreement. Where the court granting the divorce incorporates all or parts of the settlement agreement into the divorce order, it becomes an order of the court. ${ }^{270}$ In other words, failure to comply with the provisions of the deed of settlement will result in the immediate attachment of property in execution of the settlement agreement, as well as the possibility of imprisonment for contempt of court on the part of the guilty party. ${ }^{271}$

Where the court elects not to make the spouses' settlement agreement an order of the court, it can nevertheless still have legal consequences as it is a binding contract and can be enforced in the same way as any other contract. 272

In the event of the spouses not being able to reach an agreement, the

265 Alkhuli The Light of Islam 96.

266 Esposito Women in the Muslim Family (2001) 35.

267 A discussion on the law of parent and child falls outside the ambit of research undertaken for purposes of this article.

26870 of 1979.

269 Middleton v Middleton 2010 (1) SA 179 (D).

270 Swadif (Pty) Ltd v Dyke 1978 (1) SA 928 (A); PL v YL 2013 (6) SA (ECG).

271 Ibid.

272 Barratt et al Law of Persons and the Family 345. 
terms of their divorce will be decided in court. ${ }^{273}$

\section{Division of the matrimonial property}

South African divorce law is no longer based on fault or blameworthiness of a spouse as far as the grounds for divorce are concerned. However, certain consequences of divorce are influenced by who is to blame for the breakdown of the marriage, and this can cause the court to depart from the ordinary rules of division when making an order for the division of the spouses' assets. ${ }^{274}$ In other words, the effect of divorce on the division of the spouses' property depends on the matrimonial property system applicable to the marriage, and on whether the court has ordered a forfeiture of benefits in terms of section 9 of the Divorce Act or an order for spousal maintenance. Where the marriage is out of community of property and was concluded before 1984, the division of the spouses' assets can further be influenced by a redistribution order. ${ }^{275} \mathrm{In}$ applications for both a forfeiture of patrimonial benefits and redistribution orders, the conduct of the spouses is taken into account. 276

\section{(i) Forfeiture of patrimonial benefits}

Section 9 of the Divorce Act makes provision for the forfeiture of patrimonial benefits. The court, when granting an order for divorce can, depending on the circumstances of the particular case, deviate from the ordinary rules in respect of the division of the marital property and order a complete or partial forfeiture of benefits. ${ }^{277}$ In other words, in terms of a forfeiture order, the erring spouse can be deprived of some or all of the patrimonial benefits that he or she would ordinarily be entitled to by virtue of the matrimonial property regime that regulates the marriage. ${ }^{278}$ The underlying idea of section $9(1)$ is that a person should not be allowed to benefit financially from a marriage that has broken down irretrievably because he or she erred. ${ }^{279}$ Where the court grants a forfeiture order, the innocent spouse is entitled to retain such forfeited assets. ${ }^{280}$ The erring spouse does not forfeit the assets he or she brought into the marriage; he or she merely loses the claim he or she has to the assets of the other spouse. ${ }^{281}$

Where the marriage is in community of property and an order for total forfeiture has been made, the erring spouse will receive only those assets that he or she brought into the joint estate, and will not be able to claim the assets the other spouse brought into the marriage as a result of the other spouse's effort. ${ }^{282}$ Where the marriage is regulated by the accrual system,

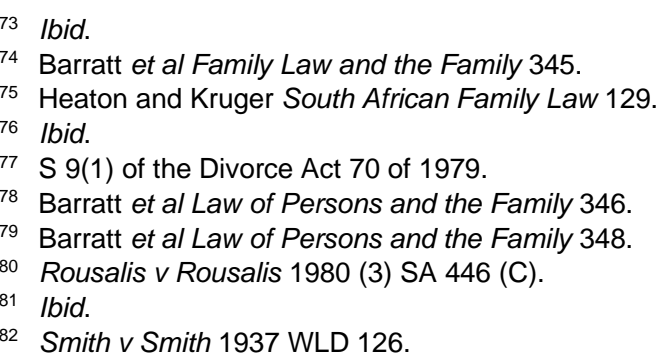


the right to share in the accrual of the other spouse's estate is forfeited. ${ }^{283}$ The court can also order the forfeiture of assets that a spouse would be entitled to in terms of an antenuptial contract. ${ }^{284}$

An order for forfeiture of patrimonial benefits will be granted if the court is satisfied that the erring spouse against whom the order is sought will be "unduly benefited" if the court does not make a forfeiture order against him or her. ${ }^{285}$ In determining whether to grant the order, the court must take into account the duration of the marriage, the circumstances that led to the breakdown of the marriage and any substantial misconduct on the part of either spouse. ${ }^{286}$ Not all these factors need be present or viewed cumulatively. ${ }^{287}$ The point of departure is to consider whether the spouse against whom the forfeiture order is sought would in fact be benefited. ${ }^{288}$ This is a purely factual issue. ${ }^{289}$ Once this has been established, the court must determine, having regard to the three above-mentioned factors, whether that spouse will be unduly benefited in relation to the other spouse if the forfeiture order is not granted. ${ }^{290}$ It must be borne in mind that the court is limited to those factors stated in the wording of section 9(1). This position was confirmed in Botha $v$ Botha, ${ }^{291}$ where it was held that, in considering whether to grant a forfeiture order, the court could not take any factors into account that fell outside those listed in section 9(1).292

As far as substantial misconduct is concerned, this is but one factor that the court takes into account, and the court can grant a forfeiture order even if there is no substantial misconduct or fault on the part of the spouse against whom the order is sought. ${ }^{293}$

A forfeiture order cannot be used to circumvent the normal consequences arising from the matrimonial property system that the parties chose to regulate their marriage. ${ }^{294}$

\section{(ii) Redistribution of patrimonial assets}

Prior to the enactment of the Matrimonial Property Act in 1984,295 if a woman did not want to be subject to her husband's marital power, the parties concluded a marriage out of community of property. The standard antenuptial contract more often than not resulted in very unfortunate consequences for the wife, who found herself in the situation where she was a housewife and mother for most of her married life, and was therefore

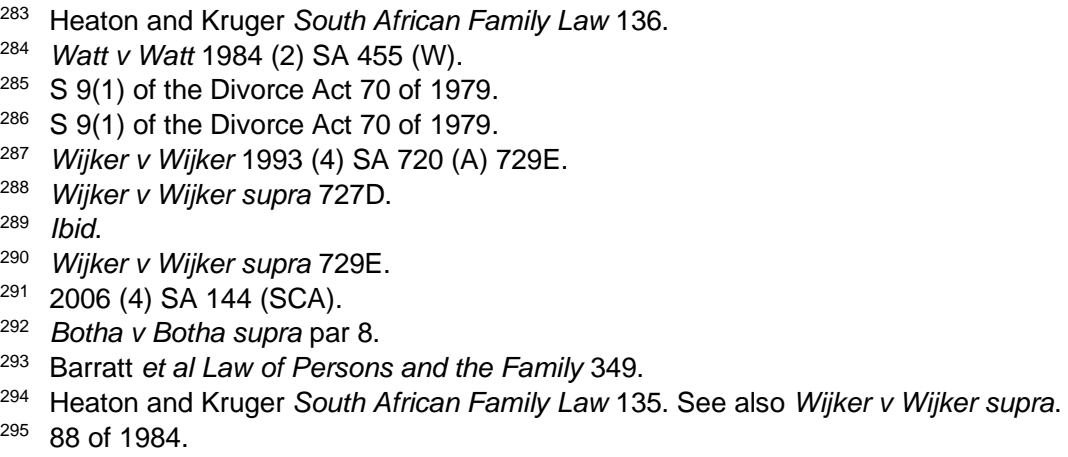


unable to amass an estate of her own. ${ }^{296}$ At the dissolution of the marriage she would not be able to share in the assets that her husband had accumulated during the subsistence of the marriage, and inevitably she would leave the marriage only with what she brought into the marriage. ${ }^{297}$ The introduction of the accrual system in 1984 brought relief to spouses who entered into a marriage after 1 November 1984. As the Act was not retrospective, the relief did not extend to marriages contracted out of community of property before 1 November $1984 .^{298}$ The legislature therefore inserted subsections (3) to (6) into section 7 of the Divorce Act. ${ }^{299}$ Subsections (3) to (6) seek to provide relief to spouses married subject to a complete separation of property prior to the enactment of the Matrimonial Property Act or the Marriage and Matrimonial Property Law Amendment Act. ${ }^{300}$

Section 7(3) bestows on the court the discretionary power to issue an order that the assets, or part of the assets, of one spouse be transferred to the other spouse in order for justice to prevail. ${ }^{301}$ The court cannot make a redistribution order of its own accord, and the party seeking redistribution must apply for the order. ${ }^{302}$

In terms of section $7(3)$, only the following spouses may apply for a redistribution order: spouses who were married prior to the commencement of the Matrimonial Property Act with an antenuptial contract that excludes community of property, community of profit and loss, and the accrual, or who were married prior to the commencement of the Marriage and Matrimonial Property Law Amendment Act in terms of section 22(6) of the Black Administration Act. ${ }^{303}$

Section 7(4) sets out two further requirements that must be met in order for the court to exercise its discretion whether to grant an order for the redistribution of assets. In terms of section 7(4), the court can only grant a redistribution order if it is satisfied that it is equitable and just because the spouse who seeks a redistribution order has contributed directly or indirectly to the maintenance or increase of the other spouse's estate during the subsistence of the marriage. The contribution by the spouse to the maintenance or increase of the other spouse's estate need not have been in monetary form. ${ }^{304}$ The contribution can be one of the following: ${ }^{305}$

(i) rendering services - for example, where the spouse works in the other spouse's business without compensation, or receives a very small

\footnotetext{
296 For a comprehensive discussion of the disadvantages of the standard form antenuptia contract, see South African Law Commission Report Pertaining to the Matrimonial Property Law (RP 26/1982) 12.1. 
salary;

(ii) saving expenses that would otherwise have been incurred - for example, by staying at home as mother and housewife; or

(iii) any other manner; in other words, any other kind of contribution would be taken into account.

The wording of section 7(4) allows the court a wide discretion to determine whether a contribution has been made by the spouse seeking a redistribution order, as the latter can request a transfer if he or she had made "any kind" of contribution towards the maintenance or increase of the other spouse's estate. ${ }^{306}$ Section 7(4) goes a long way in recognising that the role played by women as homemakers, in allowing their husbands to further their careers, should not be undervalued ${ }^{307}$ and must be afforded due weight. ${ }^{308}$

In addition to the requirements set out in section 7(3) and (4), the court is also required to take into account the factors listed in section $7(5)$. These factors are, namely, the existing means and financial obligations of the parties; any donation made by one of the parties to the other; any forfeiture order made in terms of section 9 (1) of the Divorce Act and lastly, any other factor which in the opinion of the court should be taken into account.

Although section $7(5)$ does not specifically list misconduct as one of the factors that the court can take into account, past court decisions have indicated that "any other factor" includes the misconduct of a spouse. ${ }^{309}$ While the courts have acknowledged misconduct as a relevant factor, the courts have cautioned that a conservative approach must be adopted when considering misconduct. Furthermore, the conduct of a spouse must be considered only when there is conspicuous disparity between the conduct of the spouses, especially where there has been gross misconduct. ${ }^{310}$

Where a court reaches a decision to grant a redistribution order, it has to decide what proportion of the assets must be transferred to the spouse with fewer assets. ${ }^{311}$ Previously, courts adopted the English law guideline that one-third of the spouses' combined assets should be transferred to the spouse who owns fewer assets. ${ }^{312}$ This approach was, however, rejected in Beaumont $v$ Beaumont. ${ }^{313}$ The court held that its discretion should not be limited by guidelines but that it must rather consider all the factors listed in terms of the Divorce Act, and any other factor that the court deems necessary to take into account. ${ }^{314}$ The court chose to start with a clean slate

306 Barratt et al Law of Persons and the Family 352.

307 Beaumont v Beaumont supra; Katz v Katz supra; Kirkland v Kirkland 2006 (6) SA 144 (C); Badenhorst v Badenhorst 2006 (2) SA 255 (SCA); Buttner v Buttner 2006 (3) SA (SCA).

308 Bezuidenhout v Bezuidenhout 2005 (2) SA 187 (SCA) par 29.

309 Beaumont v Beaumont supra; Buttner v Buttner supra.

310 Beaumont $v$ Beaumont supra 994-995.

311 Van Gysen v Van Gysen 1986 (1) SA 56 (C); MacGregor v MacGregor 1986 (3) SA 644(C).

312 Beaumont $v$ Beaumont supra; MacGregor v MacGregor supra.

313 Supra.

314 Beaumont $v$ Beaumont supra 991F. See also Childs $v$ Childs 2003 (2) SA 187 (SCA); Bezuidenhout v Bezuidenhout supra; Buttner v Buttner supra; Kirkland v Kirkland supra. 
to determine the extent of the redistribution. ${ }^{315}$

Mention must be made of the fact that section 7(3) may fall foul of the rights guaranteed in the Constitution - in particular, the right to equality - as redistribution orders are available only to spouses who concluded a marriage before the commencement date of the Matrimonial Property Act. ${ }^{316}$ In other words, spouses married out of community of property prior to 1984 enjoy the protection offered in terms of section 7(3), while a spouse married after 1984 will not enjoy this protection. ${ }^{317}$ The decision in Gumede $v$ President of $S A,{ }^{318}$ which allows spouses married in terms of customary law to apply for a redistribution order, regardless of when they married, and of which matrimonial property system applied to their marriage, lends weight to the argument that granting redistribution orders for spouses married in terms customary law, while denying them to others, appears to violate section 9 of the Constitution. ${ }^{319}$

\section{Spousal maintenance after divorce}

During the subsistence of a marriage, spouses have reciprocal pro rata duties to maintain each other. The general rule is that the reciprocal duty of support between spouses is terminated at the dissolution of the marriage, either by death or divorce. However, where the marriage is dissolved by divorce, the Divorce Act in section 7(1) makes provision for ongoing maintenance in terms of a settlement order concluded between the spouses.

Where the spouses cannot reach consensus, section 7(2) empowers the court to issue an order for the payment of maintenance by one spouse to the other. The maintenance order, granted in terms of section 7(2), must be granted simultaneously with the divorce order. ${ }^{320}$ In other words, a spouse will not be allowed to claim spousal maintenance once the decree of divorce has been issued. ${ }^{321}$ Prior to the Divorce Act, maintenance orders would remain in effect until the death or remarriage of the spouse in whose favour the order was granted. Cognisance was given to the fact that in the past women were not financially independent during subsistence of the marriage, and when the marriage was terminated by divorce, it was accepted that the husband would continue to support his former wife financially until she either remarried or until she died. ${ }^{322}$ Societal changes have taken place over the years and more and more women have entered the workplace. ${ }^{323}$ These changes are reflected in court decisions; on more than one occasion, courts have denied an application for maintenance where the spouse claiming maintenance was employed and was in a position to support him- or

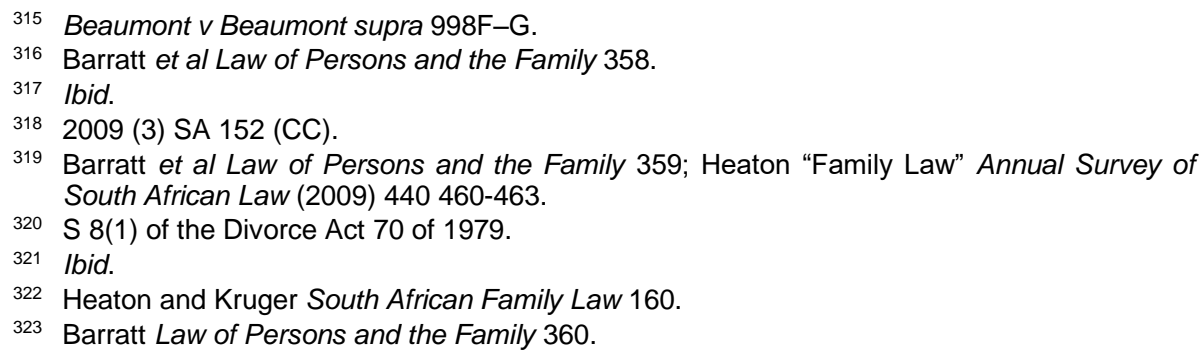


herself. ${ }^{324}$ Changes in social policy have dictated a move away from the principle that, once a marriage has been concluded, the spouse is entitled to lifelong financial support, even after the termination of the marriage. ${ }^{325}$ Where circumstances allowed, the courts have leaned towards the "cleanbreak" model of maintenance, which breaks the mould of lifelong spousal maintenance after the termination of a marriage by divorce. ${ }^{326}$ In its most extreme form, the "clean-break" principle advocates the complete termination of any economic relationship between the spouses upon divorce.327 In other words, neither of the spouses will receive, nor be required to pay, maintenance to each other.

In terms of section 7(2), if the court in exercising its discretion decides to award a maintenance order, then such an order must be just. Having stated this, the court is bound to recognise that certain situations may arise where it will be in the interests of justice to grant a maintenance order after a divorce. ${ }^{328}$ The courts have also recognised that a spouse applying for maintenance might not currently be employed, but if granted the opportunity, could be trained or retrained in order to secure employment in the future. In this instance, a court can grant a spouse rehabilitative maintenance. ${ }^{329}$ When deciding whether to grant rehabilitative or permanent maintenance, the court considers the following factors pertaining to the spouse applying for maintenance: age, earning capacity, qualifications, length of absence from the labour market, duration of the marriage, minor children born of the marriage, financial ability of the spouse against whom a maintenance order is sought to support the other spouse, and the presence of fault. ${ }^{330}$ In considering whether to grant spousal maintenance, the court is also under a constitutional obligation to promote equality between men and women. ${ }^{331}$ In some instances, however, in order to achieve substantive equality, the court is required by necessity to treat husbands and wives differently. ${ }^{332}$

Section 7(2) provides a list of factors that the court must take into account in the exercise of its discretion in deciding whether it is just or fair to grant a maintenance order. The factors listed in section 7(2) are the following: the existing or prospective means of the parties; the earning capacity of the parties; the spouses' financial needs and obligations; the age of each spouse; the spouses' standard of living prior to the dissolution of the marriage by divorce; the duration of the marriage; the conduct of the spouses as far as it is relevant to the breakdown of the marriage; whether any redistribution order has been granted; any other factor that, in the court's discretion, should be taken into account.

None of the factors listed in section 7(2) are dominant and they are not

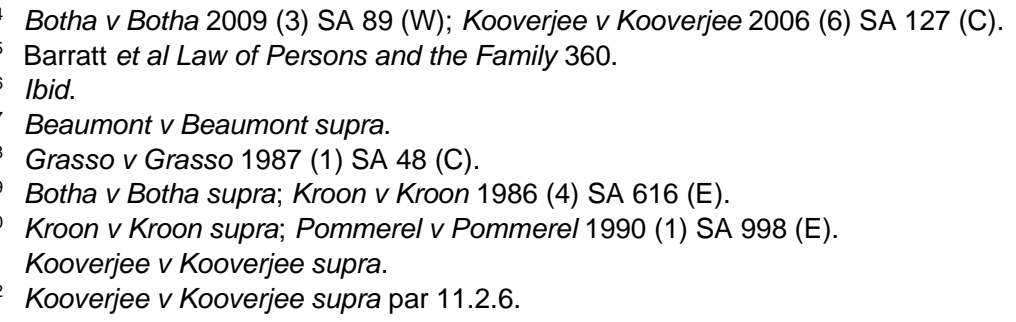


listed in order of importance. ${ }^{333}$ Furthermore, only conduct that is relevant to the breakdown of the marriage is considered, and fault assumes greater relevance if there has been gross misconduct on the part of one of the spouses. ${ }^{334}$ In the same manner that a redistribution order under section 7(3) is taken into account when a maintenance order in terms of section 7(2) is considered, a maintenance order can also be taken into account when the nature or extent of a redistribution order is to be determined. ${ }^{335}$ Section 7(2) furthermore empowers a court to take "any other factor" into account in order to issue a maintenance order that is just. Factors that the courts have, for example, taken into account, are the best interests of the minor children born of the marriage, ${ }^{336}$ the child-rearing responsibilities of the spouse claiming maintenance, ${ }^{337}$ and the inflation rate. ${ }^{338}$

\section{Inheritance}

Section 2B of the Wills Act ${ }^{339}$ provides that if a testator dies within three months of the dissolution of his or her marriage, ${ }^{340}$ any will executed prior to the dissolution of the marriage will be implemented as if his or her former spouse had died before the dissolution of the marriage and the former spouse will, therefore, not be entitled to inherit from the deceased testator's estate. This position prevails unless it is clear from the contents of the will that the testator intended his or her former spouse to inherit, notwithstanding the dissolution of the marriage. Therefore, if a testator does not want his or her former spouse to inherit, he or she must revoke the existing will. If a testator dies more than three months after the dissolution of his or her marriage and has not revoked an existing will that would have benefited his or her former spouse, the latter will inherit from the deceased testator's estate in terms of the will. ${ }^{341}$

\section{Pension-sharing orders}

Section 7(7)(a) of the Divorce Act states that a spouse's pension interest is part of that spouse's assets at divorce for the purpose of determining the patrimonial benefits to which the spouses may be entitled. ${ }^{342}$ Therefore, even where the divorce order does not expressly make mention of the spouse's pension interest, the value of the pension interest is automatically included for the purposes of determining the proprietary consequences of

\footnotetext{
333 Swart v Swart supra; Grasso v Grasso supra.

334 Swart $v$ Swart supra.

335 Heaton and Kruger South African Family Law 141.

336 Grasso v Grasso supra.

337 Kroon v Kroon supra.

338 Vedovato $v$ Vedovato 1980 (1) SA 772 (T).

3397 of 1953.

340 S 2B applies irrespective of whether the marriage was dissolved by divorce or annulment.

341 Sonnekus in Heaton (ed) Law of Divorce and Dissolution of Life Partnerships in South Africa (2014) 49-50.

342 Maharaj v Maharaj [2002] 2 All SA 34 (D); 2002 (2) SA 648 (D).
} 
the divorce. ${ }^{343}$ In terms of section $7(8)(a)$ of the Divorce Act, the court granting the divorce is empowered to order the member's fund to pay the non-member spouse's portion directly to him or her when the member spouse becomes entitled to his or her pension. ${ }^{344}$

\section{The law of England and Wales}

At divorce, little regard is paid to strict ownership rights when deciding how property should be allocated as the proprietary consequences of divorce are not determined by the marital property regime applicable to or chosen by the spouses to the marriage. However, the parties are at liberty to enter into an agreement regulating how the division of assets should be divided in the event of a divorce. ${ }^{345}$ The agreement can be concluded either before the parties enter into the marriage or after the spouses have separated. ${ }^{346}$ The agreement does not have to be made an order of the court. Private agreements between the spouses can take the form of pre-nuptial agreements, post-nuptial agreements, separation agreements, consent orders and financial dispute resolutions.

In respect of pre-nuptial agreements, the decision in Radmacher $v$ Granatino ${ }^{347}$ confirmed the validity of pre-nuptial agreements, and that it was no longer regarded as being contrary to public policy. ${ }^{348}$ In Radmacher $v$ Granatino, the approach adopted by the court was that effect should be given to a pre-nuptial agreement that was concluded with the informed consent of the spouses, each spouse appreciating the full legal implications of the agreement, unless in the prevailing circumstances it would not be fair to hold the spouses to their agreement. ${ }^{349}$ As to whether it would be fair to hold the spouses to their agreement, the court considered the factors that relate to the conclusion of the agreement, as well as those that relate to the subsequent relationship between the parties. ${ }^{350} \mathrm{~A}$ pre-nuptial agreement is deemed to carry more weight if both spouses received independent legal advice before the conclusion of the agreement; if there was full disclosure of all assets by each spouse; and where there was no duress or undue pressure to conclude the agreement. ${ }^{351}$ However, even where the pre-nuptial agreement was freely concluded with full disclosure, it will not automatically be upheld in a court of law. ${ }^{352}$

343 Fritz $v$ Fundsatwork Umbrella Pension Fund 2013 (4) SA 492 (ECP); Macallister v Macallister [2013] JOL 30404 (KZD); Kotze v Kotze [2013] JOL 30037 (WCC); Motsetse v Motsetse [2015] 2 All SA 495 (FB) and Ndaba $v$ Ndaba [2017] 1 All SA 33 SCA.

344 See also s 37D(1)(d)(i) of the Pension Funds Act 24 of 1956.

345 Probert Family and Succession Law in England and Wales 192.

346 Ibid.

347 [2010] UKSC 42.

348 Radmacher v Granatino [2010] UKSC 42 par 52.

349 Radmacher $v$ Granatino supra par 75.

350 lbid.

351 Kremen $v$ Agrest (N0.11) (Financial Remedy: Non-disclosure: Post-Nuptial Agreement [2012] EWHC 45 (Fam), par 74; GS $v$ L [2011] EWHC 1759b (Fam), par 77; B v S (Financial Remedy: Marital Property Regime [2012] EWHC 265 (Fam), par 20.

352 Radmacher $v$ Granatino supra par 77. 
Furthermore, the court held in Radmacher $v$ Granatino that there was no material distinction between pre-nuptial and post-nuptial agreements. ${ }^{353}$ Post-nuptial agreements would therefore be enforceable between the spouses, even if they were not capable of binding the court. ${ }^{354}$

The existence of a separation agreement will be taken into consideration by a court in exercising its discretion to achieve an outcome that is just and fair as stipulated under section 25 of the Matrimonial Causes Act 1973. The pertinent questions that a court has to ask in this respect are:355

(i) How was the separation agreement made?

(ii) Did the parties attach importance to it?

(iii) Have the parties acted on the separation agreement?

Courts will more likely than not uphold a separation agreement entered into between the spouses unless there is very good reason to depart from its terms. ${ }^{356}$

Spouses who enter into a written settlement agreement in which they agree on the division of their assets can approach a court to make a consent order on the terms agreed. ${ }^{357}$ The consent order constitutes an order of the court that makes it more difficult to challenge. ${ }^{358}$ A court order will be overturned only if there is proof of some element that vitiates the basis of the order. 359

In order to encourage parties to come to a settlement in respect of the division of their assets, financial dispute resolution was introduced in 2000. Financial dispute resolution consists of strong judicial case management as well as an "early neutral evaluation" by a judge as to what order would possibly be granted if the parties went to court. ${ }^{360}$ The agreement reached by the spouses as a consequence of the financial dispute resolution is deemed to be a binding order of court. 361

\section{Division of matrimonial property}

The Matrimonial Causes Act gives the court extensive powers to issue a range of financial orders;362 property adjustment orders;363 pension-sharing orders; 364 and orders for the sale of any property belonging to the

353 Radmacher v Granatino supra par 60.

354 Radmacher v Granatino supra par 60. See also MacLeod v MacLeod [2008] UKPC 68.

355 G v G (Financial Provision: Separation Agreement) [2000] 2 F.L.R. 18 FD.

356 Edgar v Edgar [1980] 1 WLR 1410. For example, the presence of fraud, duress and undue influence.

357 S 33A of the Matrimonial Causes Act 1973.

358 De Lasala v De Lasala [1980] A.C. 546.

359 Rose $v$ Rose [2002] EWCA Civ 208. For example, misrepresentation, mistake, or material non-disclosure.

360 Rose v Rose [2002] 1 F.L.R. 978.

361 Ibid.

362 S 23 of the Matrimonial Causes Act 1973 allows the court to make orders for secured or unsecured periodical payments or a lump-sum payment.

363 S 24 of the Matrimonial Causes Act 1973 allows a court to make orders for the transfer or settlement or property, or for the variation of an existing settlement.

364 S 24B of the Matrimonial Causes Act 1973. 
spouses. ${ }^{365}$ Section 25(2) provides the list of factors that the court takes into account to determine how the assets should be divided on divorce. The list of factors provided for in terms of section 25(2) is not exhaustive as the courts are also instructed in terms of section 25(1) to have regard to all the circumstances of the case. In practice, courts tend to focus on the needs of the spouses and the children born of the marriage, and therefore in a case involving spouses with modest assets, the primary caregiver have more often than not been given more than half of the estate. ${ }^{366}$ In contrast, where divorcing spouses are wealthy, the spouse who has not personally generated the wealth, has been allocated significantly less than half of the assets. ${ }^{367}$

The decision of the House of Lords in White $v$ White 368 heralded a change in the courts' approach insofar as the allocation of assets between divorcing spouses is concerned, as the court held that the primary objective in applying the Matrimonial Causes Act is to achieve a fair outcome between the spouses. ${ }^{369}$ Lord Nicholls, who delivered the main judgment, emphasised that in order to achieve a fair outcome between divorcing spouses, there should be no discrimination between husband and wife and their respective roles, and furthermore, there should be no bias against the homemaker in favour of the spouse who has amassed assets. ${ }^{370}$ The consequence of the decision in White $v$ White has been that courts have been prepared to award wives a larger share of the assets where the divorcing parties are very wealthy. 371

The key principles in respect of the allocation of assets of divorcing parties as formulated by case law are first that the focus of the courts will primarily be on meeting the needs of the children and their primary caregiver where resources of the spouses are insufficient to meet their needs. ${ }^{372}$ Secondly, where divorcing spouses have more than sufficient resources to meet their needs, these resources may be shared depending on the source of the resources, the contributions of the spouses and all the circumstances of the case. ${ }^{373}$

\section{Maintenance}

In respect of post-spousal maintenance, a court is also required to consider the desirability of a clean break between divorcing spouses insofar as the economic consequences of the divorce are concerned. ${ }^{374}$ For example, a court must consider whether it would be appropriate to exercise its powers to ensure that the financial obligations of the divorcing spouses are terminated

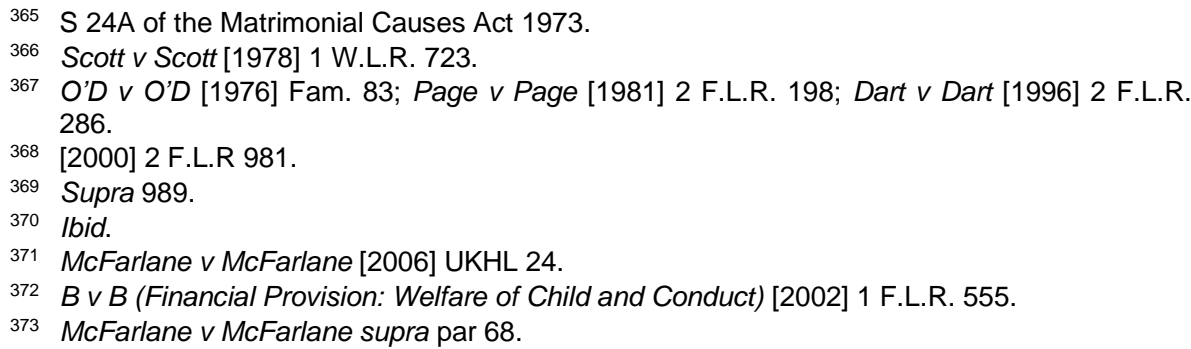


as soon as possible after a decree of divorce. ${ }^{375}$ The desirability of a clean break may also influence whether the provision is made by way of lump-sum or periodical payments, but it cannot affect the actual amount deemed appropriate. ${ }^{376}$

Where the court makes an order for periodical payments, the court is also required to consider whether it would be appropriate to specify the time period for which the order should last. ${ }^{377}$ The court can furthermore direct that no application should be made in the future to increase the period of time. ${ }^{378}$ Cognisance must be taken of the fact that periodical payments will automatically terminate where the recipient remarries. ${ }^{379}$ Where the recipient merely cohabits with a third party, it is within the court's discretion whether or not the payments should cease. ${ }^{380}$

In terms of section 23(1)(b) of the Matrimonial Causes Act 1973, an order for secured periodical payments can also be made, and be effective even after the death of the payer. ${ }^{381}$ Orders for secured periodical payments are generally made where the payer has a bad track record or he or she might leave the country to work elsewhere, and simultaneously take assets out of the jurisdiction of the court, and where the payer is particularly wealthy or impecunious and it is necessary to protect the position of the payee. ${ }^{382}$

\section{Inheritance}

In terms of article 26 of the Inheritance Act 1962, the right of succession between spouses is cancelled by legal separation, divorce, and by the voiding of their marriage by judgment.

\section{Pension-sharing orders}

The courts are also empowered to make two types of order in respect of a spouse's pension - namely, an order for attachment of the spouse's pension ${ }^{383}$ or an order for pension-sharing. In terms of an attachment order, the court makes an order for that part of the pension to be paid directly to the ex-spouse when it falls due. ${ }^{384}$ The disadvantages of this order are that the ex-spouse is required to wait until the pension becomes due, and it is also uncertain what the value of the pension will be when it is eventually paid. ${ }^{385}$ The preferred order is an order for pension-sharing in terms of which the person's pension right is shared with the ex-spouse, who can either leave it

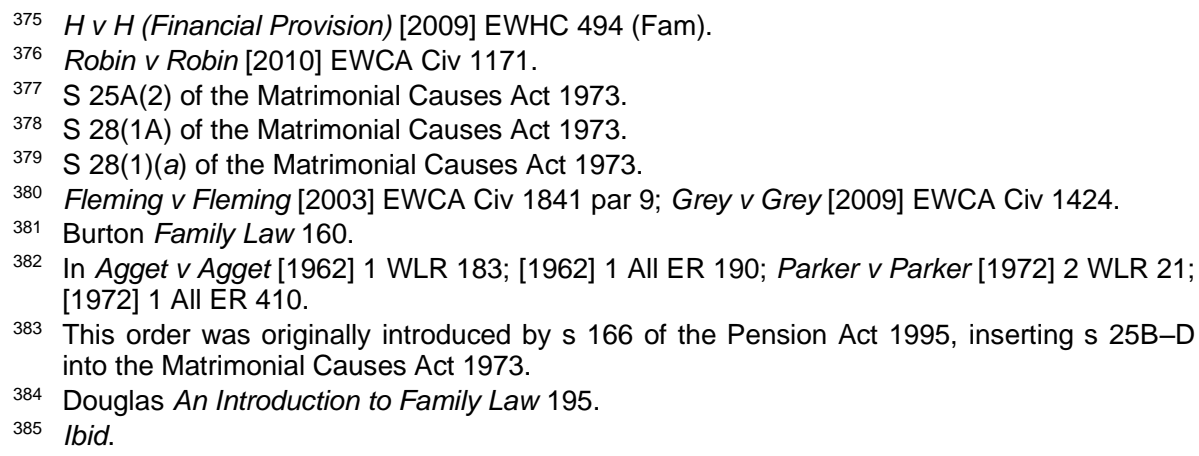


in the pension scheme, or reinvest it elsewhere. ${ }^{386}$ This enables the exspouse to receive the benefits of the pension as if he or she had accrued them independently of the circumstances of the other spouse. ${ }^{387}$

\section{Comparison}

There are stark differences between Islamic, South African and English law insofar as the economic consequences flowing from divorce are concerned. The matrimonial property regime of a marriage concluded in terms of Islamic rites is one of complete separation. Both spouses therefore leave the marriage on divorce with their separate assets. Unlike South African and English law, Islamic law does not make provision for the sharing of assets at the termination of the marriage on divorce. In particular, the claim for the forfeiture of patrimonial benefits and a redistribution order that is allowed in terms of South African divorce law is foreign to Islamic law. In South African law, the division of the marital assets is determined by the matrimonial property regime regulating the spouses' marriage. In contrast, in terms of English law, the division of matrimonial property at divorce is determined by the courts, unless the parties have entered into private agreements in respect of their estates.

It is also clear from the discussion above that the position in Islamic law with regard to the post-divorce maintenance differs from that in South African and English law in the following respects: first, the duty of maintenance in South African law is reciprocal during the marriage, and the duty rests on both husband and wife depending on their circumstances, while in Islam the duty falls only on the husband. Secondly, in South African law, the duty to maintain terminates at the date of divorce, unless there is an agreement between the parties to the contrary, or a court order to that effect. In Islam, maintenance of the wife terminates three months after the divorce. In other words, the husband's spousal duty of support does not extend beyond the iddah period, and after the iddah period, the husband ceases to be responsible for the maintenance of his ex-wife. There is no provision for the duty to continue, either by agreement or by court order. The exception to this rule is when the ex-wife is pregnant or where she is still breastfeeding.

Unlike South African and English law, in Islamic law, arrear maintenance is regarded as a debt against the husband that does not prescribe.

South African and English law do not require the husband to pay dower to his wife, and therefore there is no need for rules regulating the dower at the dissolution of a marriage as is the case in Islamic law.

In respect of Islamic law, the dissolution of a marriage by divorce does not necessarily terminate the rights of succession between the parties; in the case of a revocable divorce, the surviving spouse is entitled to inherit from the deceased if either spouse dies during the iddah period. In South African law, the rights of succession between spouses are terminated at divorce unless the provisions of section $2 \mathrm{~B}$ of the Will Act are applicable. The rights 
of succession between spouses are cancelled at the termination of a marriage in terms of English law.

While both South African and English law make provision for pensionsharing orders, there is no similar provision in Islamic law.

\section{CONCLUSION}

The purpose of this article is to highlight the fundamental differences with regard to the principles and rules governing the termination of a marriage, either by death of one or both spouses or by a divorce in Islamic, South African and English law. The aim has been to emphasise that Islamic law will never completely comply with international equality rights or with the South African Constitution. Furthermore, as Islamic law is regarded as divine law, it is highly improbable that major changes to Muslim Personal Law to bring it in line with the Constitution, in particular gender equality, will be acceptable to adherents of the Muslim faith.

While all three legal systems recognise the importance of marriage as the cornerstone of society and that the dissolution of a marriage through divorce should be embarked on as a last resort, all three legal systems have developed a comprehensive set of rules and principles regulating divorce. Each legal system, however, has its own provisions in respect of law relating to divorce. Underlying the various sets of rules of divorce are Islamic legal theories vis-à-vis human rights and gender legal theories. It is clear from the comparative analysis of divorce law that Islamic divorce law is irreconcilable with the Western human-rights approach adopted by South Africa and England and Wales in respect of divorce law. In particular, the right to equality and the right to freedom of religion is at the crux of the dilemma. Legal principles firmly established in Islamic law appear to be in direct conflict with gender equality and human rights. Where these rights prove to be irreconcilable, the question arises whether Islamic law should bow to the Constitution (which would essentially involve changing and adapting Islamic law to accommodate the Constitution) or whether the Constitution should be adapted to accommodate Islamic law. It must be borne in mind that, although Islamic divorce law may appear oppressive as far as the rights of women are concerned, the overall spirit of Islamic divorce law lays emphasis on both equity and decent behaviour between the parties.

The comparison between the three legal systems clearly demonstrates that, while there are some similar underlying principles, the rules and principles in Islamic law are clearly fundamentally different from those of South African law and English law. The attempts to give effect to the consequences of marriages concluded in terms of Muslim rites in both South African law and English law have led to a unique set of rules that are not always Shari'ah compliant and which will ultimately lead to the emergence of a distorted set of laws relating to Muslim family law. The result is that profound difficulties are experienced by Muslims who practise MPL and live in South Africa, England and Wales. 